\title{
norden
}

\section{Tuition fees for international students}

Nordic practice

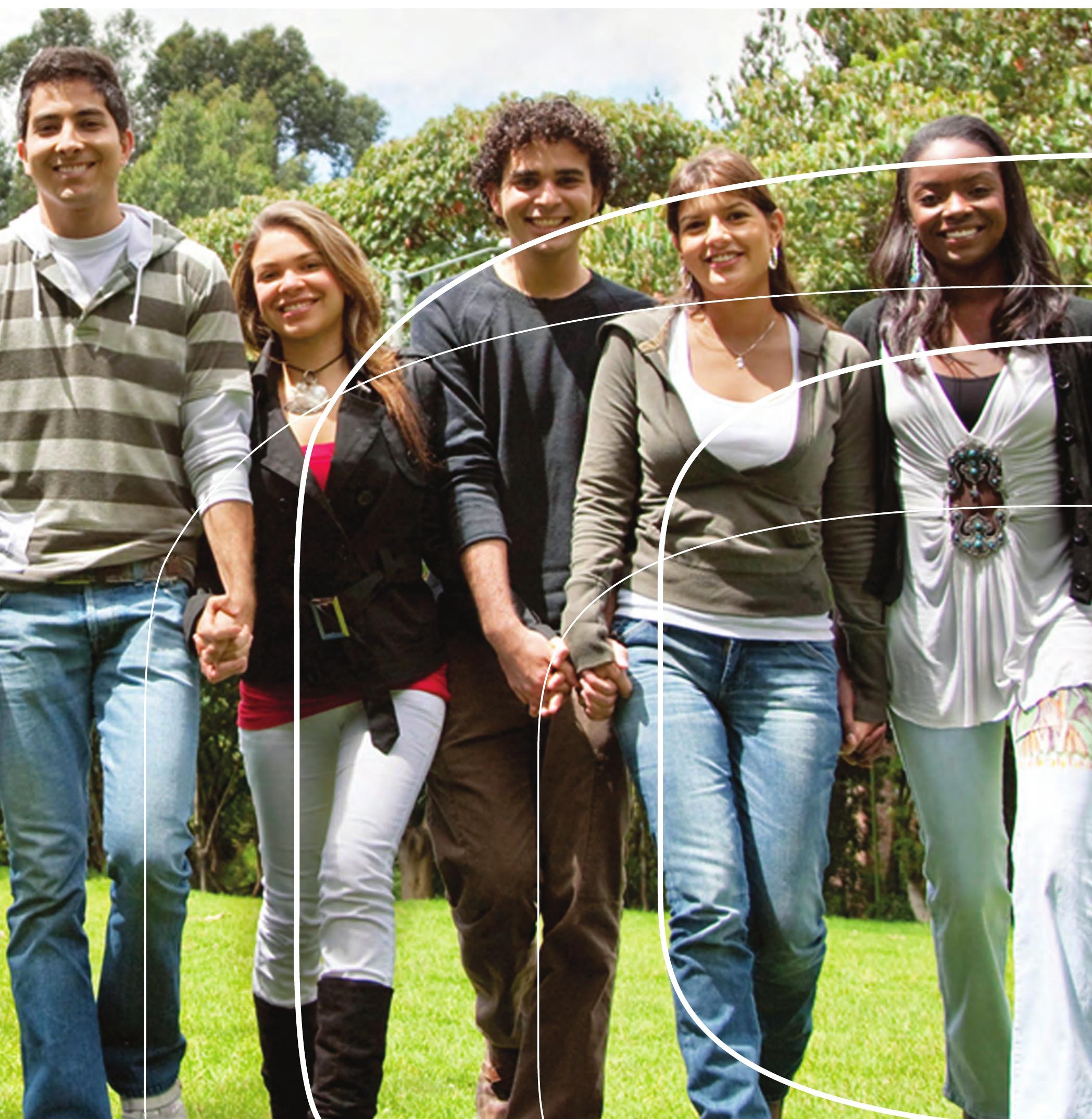



4 norden 



\section{Tuition fees for international students}

Nordic practice

Oxford Research

TemaNord 2013:516 
Tuition fees for international students

Nordic practice

Oxford Research

ISBN 978-92-893-2515-8

http://dx.doi.org/10.6027/TN2013-516

TemaNord 2013:516

(C) Nordic Council of Ministers 2013

Layout: Hanne Lebech/NMR

Cover photo: Andres Rodriquez

Print: Rosendahl-Schultz Grafisk

Copies: 130

Printed in Denmark

This publication has been published with financial support by the Nordic Council of Ministers. However, the contents of this publication do not necessarily reflect the views, policies or recommendations of the Nordic Council of Ministers.

www.norden.org/en/publications

Nordic co-operation

Nordic co-operation is one of the world's most extensive forms of regional collaboration, involving Denmark, Finland, Iceland, Norway, Sweden, and the Faroe Islands, Greenland, and Åland.

Nordic co-operation has firm traditions in politics, the economy, and culture. It plays an important role in European and international collaboration, and aims at creating a strong Nordic community in a strong Europe.

Nordic co-operation seeks to safeguard Nordic and regional interests and principles in the global community. Common Nordic values help the region solidify its position as one of the world's most innovative and competitive.

Nordic Council of Ministers

Ved Stranden 18

DK-1061 Copenhagen K

Phone (+45) 33960200

www.norden.org 


\section{Content}

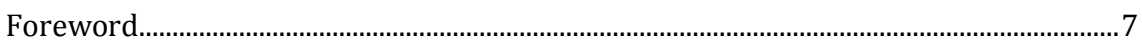

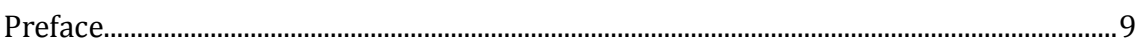

Executive summary .................................................................................................... 11

1. Tuition fees in Nordic higher education ................................................................. 13

1.1 Tuition fees in Finland ............................................................................... 14

1.2 Tuition fees in Norway ....................................................................................... 18

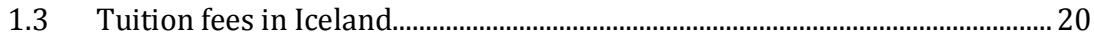

$1.4 \quad$ Tuition fees in Denmark....................................................................................... 22

1.5 Tuition fees in Sweden................................................................................... 28

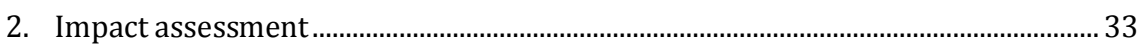

2.1 Impact of tuition fees in the Nordic countries................................................. 33

2.2 Consequences for Nordic co-operation ............................................................. 49

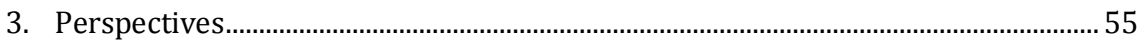

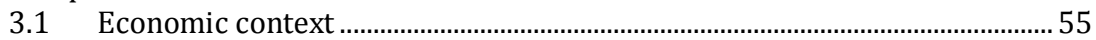

3.2 Arguments for and against tuition fees ........................................................ 58

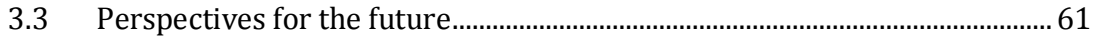

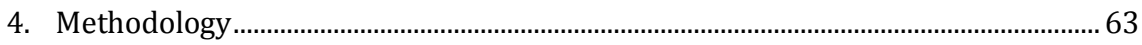

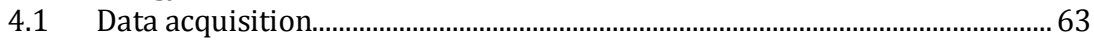

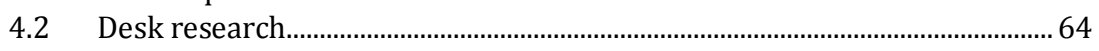

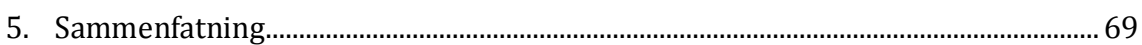





\section{Foreword}

Higher education is deemed to be strategically important for the future of the Nordic welfare model. Education provides people with the opportunity to make choices and shape their own lives. A well-educated population is also a crucial competitive parameter in an increasingly global economy.

Throughout the world, the number of students moving across national borders to study has risen dramatically in the last decade. Interest in the Nordic Region has grown, particularly in countries outside Europe. Nordic higher education now has to compete in a truly global market, one in which competition is tough and institutions work hard to attract the best students.

Most EEA countries charge some form of tuition fee for foreign "third-country students." The costs vary from small registration fees to

full tuition fees that cover a whole study programme. In some countries, fees are regulated centrally, in others the institutions decide. Until a few years ago, the Nordic countries had a long tradition of free higher education financed by the taxpayers. That situation has now changed. Denmark was the first to introduce tuition fees in 2006. Finland launched a five-year trial period in 2010, while Sweden brought in fees from autumn semester 2011. Iceland and Norway do not charge tuition fees.

There are multiple aspects to the issue of tuition fees, and the rapidly changing nature of the situation necessitated further analysis. We need greater insight into the different models, and we also need to learn from each other in the Nordic Region. Several questions and arguments need to be posed, addressed, highlighted and evaluated. For example, what kinds of arguments are used for and against the introduction of tuition fees? How are the systems constructed and applied in different countries? What kind of effects, if any, are seen when fees are introduced? What models exist for scholarship schemes, and how do they work in practice? 
The Nordic Council of Ministers commissioned Oxford Research to conduct this study. The remit has been to provide a knowledge base for further co-operation within Nordic higher education. The report presents an overview of the current status and consequences to date. I commend it to everybody interested in the issue of tuition fees and trust that it will provide you with valuable new insights and knowledge.

Oslo, 21. January 2013

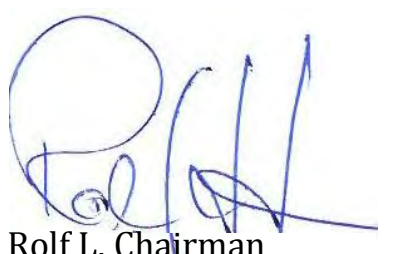

Rolf L. Chairman

Advisory Group for Nordic Co-operation

on Higher Education (HøGUT) 


\section{Preface}

Over the last 10-15 years, the education market has become increasingly international, leading to a general increase in student mobility and fierce global competition to attract the best students.

The annual OECD comparative study of world education shows that 3.7 million students are currently enrolled on higher education programmes outside their native country, half of them in Europe. ${ }^{1}$

At global level, the Nordic countries are among those with the highest proportion of state funding of higher education (HE). For a long time, they stood out from the other Western countries by not imposing tuition fees on international students. However, in recent years, a shift in emphasis in education policy and reforms in the education systems have brought the Nordic countries more closely into line with the other Western nations. In 2006, Denmark became the first country in the Region to introduce tuition fees for non-EU/EEA students. ${ }^{2}$ In 2010, the Finnish Parliament introduced fees on a trial basis, and Sweden introduced a model similar to the Danish one in 2011.

This Oxford Research study principally focuses on national practices concerning international students. ${ }^{3}$ In particular, it addresses three aspects of tuition fees in the Nordic Region. Part one identifies practice with regard to tuition fees in the HE sector, i.e. the basis for their introduction, trends in the number of international students and current practice in relation to scholarships. Part two focuses on the impact of the introduction of fees, explains the trends in the number of international students and maps the consequences at Nordic level. Part three focuses on perspectives for the future and presents arguments for and against the introduction of tuition fees, taking into account other perspectives that are relevant in the Nordic context.

During the course of this study, Oxford Research had the pleasure and privilege of meeting and talking with a number of inspiring individuals associated with the issues concerned, e.g. representatives from government departments, boards of directors, universities, colleges, etc. We thank you all for making your time and knowledge available to us.

\footnotetext{
1 OECD (2011): Education at a Glance, p.321

2 The EU/EEA countries comprise the EU member states plus Norway, Liechtenstein, Iceland and Switzerland. 3 International students are defined in this context as students from countries outside the EU/EEA (except Switzerland, Norway, Iceland and Liechtenstein).
} 
We hope that this study will provide an informed basis for further work in the area and that you will find it both enlightening and useful.

Oxford Research A/S, December 2012 


\section{Executive summary}

This study concerns the different practices in the Nordic countries regarding the implementation of tuition fees for international students. ${ }^{4}$

The study is based on three complementary approaches. The first part consists of a mapping of the current status of tuition fees across the Nordic countries. This is done by identifying students who pay fees, quantifying the number of international students in each Nordic country, and describing the process of allocating scholarships. The second part focuses on the impact of tuition fees in the Nordic countries, and outlines and explains the patterns for international student numbers and how they relate to fees. The potential consequences for the Nordic Region are also outlined. The final part of the study assesses potential future developments in a Nordic context.

The mapping exercise shows that three of the five Nordic countries have introduced tuition fees in higher education - however, it is important to note that tuition fees are limited to students from outside the EU/EEA. ${ }^{5}$ Moreover, the application of fees varies between these three countries. Denmark introduced fees in 2006, and therefore has the most experience in this area. Tuition fees have since been applied to all HE programmes in Denmark. This is also the case in Sweden. However, as tuition fees were only introduced in 2011, Sweden has as yet only fairly limited experience of them. The third country that has introduced tuition fees is Finland, where a pilot project has been initiated for the period 2010-2014. Norway and Iceland have not introduced tuition fees. Generally speaking, all international students can pursue a degree in these countries without being subject to fees.

The consequences of the introduction of tuition fees are very different. Denmark and Sweden, which have implemented fees on a large scale, have experienced a severe drop in the number of international students from non-EU/EEA countries. In Denmark, this drop was followed by a significant rise in the number of non-EU/EEA students two to three years after fees were introduced. This was due mainly to the widespread system of scholarships for these students, as well as to marketing initiatives. The number of non-EU/EEA students at Swedish HE institu-

\footnotetext{
${ }^{4}$ In this context, "international students" refers to those from non-EU/EEA countries, except Norway, Liechtenstein, Iceland and Switzerland.

${ }^{5}$ The EU/EEA countries consist of the EU member states plus Norway, Liechtenstein, Iceland, and Switzerland.
} 
tions fell from approximately 8,000 in 2010 to approximately 2,000 in 2011. In both Denmark and Sweden, the decline was primarily due to a decrease in the number of students from Asia. To alter this pattern, Sweden has introduced several initiatives, including broad marketing campaigns and increased funding for scholarships.

In Finland, the findings emerging from the pilot project are, as yet, on too small a scale to generate a clear understanding of any impact. The two universities with the largest number of programmes that charge fees will continue to apply fees to more programmes up until 2014. This will enable them to gain more experience prior to implementing permanent change.

In Norway and Iceland, the number of international students has increased within the last five to seven years. This has included significant numbers of non-EU/EEA students, which suggests that these students are choosing programmes in Norway and Iceland as a result of the tuition fees in the other Nordic countries.

The study's assessment of potential future developments regarding the implementation of tuition fees shows that the differences in policy between the Nordic countries are the result of conscious choices. Which policy should be implemented and the pros and cons of tuition fees are fundamental issues for the Nordic countries. This discussion of fees is inherently linked to the debate about the future scope of the welfare state and the financial resources of the Nordic countries, as well as the role of international students in economic development. 


\section{Tuition fees in Nordic higher education}

This study looks at tuition fees in the Nordic Region. More specifically, it focuses on students from non-EU/EEA countries, as it is they who have to pay to study in countries that have introduced tuition fees. ${ }^{6}$

This mapping exercise reveals distinct differences in relation to tuition fees across the Nordic countries. Only Denmark has significant (six years') experience of fees. Sweden only recently fully introduced fees, while Finland has only introduced them for a "trial period." Norway charges no fees, and Iceland only charges a small annual administration fee.

Table 1: Tuition fees in the Nordic Region

\begin{tabular}{|c|c|c|c|c|c|}
\hline & Denmark & Sweden & Norway & Finland & Iceland \\
\hline $\begin{array}{l}\text { Fees } \\
\text { introduced }\end{array}$ & 1 August $2006^{7}$ & 1 July 2011 & $\mathrm{~N} / \mathrm{A}$ & $\begin{array}{l}\text { 2010-2014 } \\
\text { (five-year "trial } \\
\text { period") }\end{array}$ & $\begin{array}{l}\text { N/A (registra- } \\
\text { tion fee) }\end{array}$ \\
\hline Amount & $€ 6,200-13,100$ р.а. & $\begin{array}{l}€ 6,500- \\
15,500 \text { p.a. }\end{array}$ & $\begin{array}{l}\text { N/A in } \\
\text { public- } \\
\text { sector HE }\end{array}$ & $\begin{array}{l}€ 5,000-12,000 \\
\text { p.a. Optional } \\
\text { for institu- } \\
\text { tions, and } \\
\text { amounts vary }\end{array}$ & $\begin{array}{l}\text { N/A for public- } \\
\text { sector univer- } \\
\text { sities, annual } \\
\text { admin fee of } \\
\text { approx. €350 }\end{array}$ \\
\hline $\begin{array}{l}\text { Study } \\
\text { pro- } \\
\text { grammes }\end{array}$ & $\begin{array}{l}\text { Bachelor and Profes- } \\
\text { sional Bachelor pro- } \\
\text { grammes, Academy } \\
\text { Profession pro- } \\
\text { grammes and pro- } \\
\text { grammes at other HE } \\
\text { institutions }\end{array}$ & $\begin{array}{l}\text { Universities } \\
\text { and colleges }\end{array}$ & $\begin{array}{l}\text { Universities, } \\
\text { colleges of } \\
\text { science and } \\
\text { colleges }\end{array}$ & $\begin{array}{l}\text { Universities } \\
\text { and polytech- } \\
\text { nics }\end{array}$ & $\begin{array}{l}\text { Universities } \\
\text { (colleges) }\end{array}$ \\
\hline
\end{tabular}

How this has worked in practice in each individual country will be discussed in more detail later in this chapter, in connection with mapping the state of play of tuition fees across the Region. For each country, this takes the form of a general picture of the status of tuition fees and international students, and an overview of relevant legislation and the scholarship system.

\footnotetext{
${ }^{6}$ However, a number of exceptions apply in Denmark, Sweden and Finland, i.e. students who come to the country on an exchange programme, citizens of a third country with permanent residence permits, and citizens of third countries who have temporary residence permits in the country for reasons other than education.

${ }^{7}$ Only for students from countries outside the EU/EEA (except Switzerland) - this applies to all of the Nordic countries that have introduced tuition fees.
} 
To map the status of tuition fees, this part of the study utilises data about all students registered at Nordic HE institutions, focusing on trends in the number of international students. It is vital to identify the number of students enrolled at Nordic HE institutions at a particular point in time. ${ }^{8}$ The subsequent impact analysis (Chapter 2) exclusively uses figures for new students at HE institutions in the Region, in order to isolate the effect of any changes to legislation in the respective countries.

\subsection{Tuition fees in Finland}

In June 2009, as part of the reform of its University Act, Finland decided to introduce a pilot project for tuition fees, running from 2010 until 2014. The reform also granted universities greater autonomy. ${ }^{9}$ Prior to the reform, students at universities or other HE institutions did not have to pay fees.

At present, it is up to the universities and polytechnics ${ }^{10}$ to decide whether to participate in the trial. As a result, some study programmes in Finland charge fees and others do not. During the trial period, a decision will be made on whether to make tuition fees permanent for nonEU/EEA students.

In Finland, 399 study programmes were eligible to participate in the pilot project from $2010-2014 .{ }^{11} \mathrm{~A}$ total of 41 are currently charging fees to non-EU/EEA students, spread across nine universities and ten "polytechnics."12 The legislation stipulates that HE institutions taking part in the pilot project must also offer a scholarship scheme. ${ }^{13}$ The programmes must be taught through the medium of English and be at Master's level. ${ }^{14}$

The study found that the programmes involved in the trial are also the ones that are considered to be the best:

"At Aalto University, it was decided that the best-quality programmes should be used for the tuition fees trial" (Researcher, Finland)

\footnotetext{
${ }^{8}$ The fact that not all of the Nordic countries systematically register international students' countries of origin also had a significant impact on the mapping exercise, and made it difficult to present trends for international students. This will be covered in greater depth in Chapter 2.

${ }^{9} \mathrm{http} / /$ www.minedu.fi/

10 The term "polytechnic" refers to the HE institutions called "Yrkeshögskola" (vocational colleges) in Finland-Swedish.

11 One of the conditions for participation was that the programmes had to be run in English.

12 Interview with L. Wiemer PhD and Birgitta Vuorinen, Counsellor for Education, Ministry of Education.

$13 \mathrm{http} / /$ www.minedu.fi/

14 This applies to both universities and polytechnics. See http://www.studyinfinland.fi/instancedata/ prime_product_julkaisu/cimo/embeds/studyinfinlandwwwstructure/21156_Tuition_fees_UAS_Master_ Programmes.pdf
} 
This suggests that the programmes that the institutions rate as the most attractive to international students are the ones included in the pilot project.

Since the pilot project has not been going for very long, Finland has limited experience of tuition fees. However, the study ${ }^{15}$ reveals both positive and less positive experiences. On the positive side, some Finnish stakeholders (e.g. civil servants and representatives of some universities) think that trialling tuition fees is a good thing, as they do not believe that the current financial model for HE is sustainable. On the negative side, other stakeholders (e.g. representatives of students and other universities) fear that the pilot project is the first step towards a general introduction of tuition fees in Finland. Other stakeholders point out that the pilot project is not functioning optimally, as too few programmes are included to enable a proper evaluation of whether tuition fees are a good idea in Finland in general. They also point out that there is no incentive for universities to invest in the idea, because they do not know what will happen in the long term.

In autumn 2012, the Finnish pilot project was evaluated to determine whether and how it should continue. The official position of Universities Finland is that it should. ${ }^{16}$ In August 2012, the two universities ${ }^{17}$ with the most programmes involved in the pilot project announced that they would extend the experiment throughout the period, and introduce fees for more of their programmes in the final couple of years up to until $2014 .{ }^{18}$

\subsubsection{Implementation of the legislation}

The Act that governs the pilot project is designed to allow universities to set the price for their own programmes. This can be done at university level or at faculty level. The universities in Finland charge more or less the same rates as for Erasmus Mundus programmes in the EU. The rationale for this is that it is the simplest way of setting prices and reflects market conditions.

\footnotetext{
"The three programmes are a part of Erasmus Mundus because this was easiest. Students pay €8,000 a year, which is fixed by the Erasmus Mundus programme" (Representative, Finnish university)
}

Generally speaking, fees in Finland are currently approximately €78,000 p.a. For example, Aalto University charges international nonEU/EEA students a fixed price of $€ 8,000$ p.a. for all of its programmes.

\footnotetext{
15 Autumn 2012.

16 Interview with Kaija Holli, Chair of Universities Finland.

17 Aalto and Jyväskylä.

18 http://yle.fi/uutiset/rehtorit_jatkaisivat_lukukausimaksukokeilua_-_hyoty_viela_olematon/6266802
} 
The price is based on experience with Erasmus Mundus, but also reflects a deliberate decision to set prices at a high level in order to quantify the impact of introducing tuition fees:

\footnotetext{
"The Erasmus Mundus consortia, in which Aalto University is a partner, also charge the same tuition of $€ 8,000$ per academic year. It was a conscious decision to set one consistent fee for all programmes. The level of tuition was also set high enough to view the possible effects of the tuition fees." (Official statement by Aalto University)
}

\subsubsection{Number of students at universities and polytechnics}

The HE sector in Finland comprises 14 universities and 25 polytechnics. The universities offer programmes at PhD, Master's and Bachelor level, while polytechnics mainly offer programmes at Bachelor level.

In 2010, the total number of HE students in Finland was 308,256. This figure has been stable since 2005. In the period 2005-2010, there was a marginal fall of $588(0.2 \%)$ in the total number of students in Finland. In $2010,55 \%$ of the total student population were studying at universities, the remaining $45 \%$ at polytechnics. In 2010 , international students were split approximately $50 / 50$ between the two types of institution.

In general, the pattern for HE in Finland is for the number of international students to increase - by 75\% between 2005 and 2010. Table 2 shows the numbers of international students in Finland, broken down into EU/EEA students and non-EU/EEA students.

Table 2: Number of international students in Finland

\begin{tabular}{lrrr}
\hline Students & 2005 (no. of students) & 2010 (no. of students) & Change (\%) \\
\hline EU/EEA total & $\mathbf{4 , 1 0 9}$ & $\mathbf{5 , 1 2 3}$ & $\mathbf{+ 2 5 \%}$ \\
Universities & $(2,559)$ & $(3,148)$ & $(+23 \%)$ \\
Polytechnics & $(1,550)$ & $(1,975)$ & $(+27 \%)$ \\
Non-EU/EEA total & $\mathbf{4 , 8 4 6}$ & $\mathbf{1 0 , 5 8 4}$ & $\mathbf{+ 1 1 8 \%}$ \\
Universities & $(2,390)$ & $(4,667)$ & $(+102 \%)$ \\
Polytechnics & $(2,456)$ & $(5,917)$ & $(+137 \%)$ \\
Total & 8,955 & 15,707 & $+\mathbf{7 5 \%}$ \\
\hline
\end{tabular}

Source: Statistics Finland, Educational Statistics.

Table 2 shows that this trend is primarily driven by two factors. Firstly, there has been a marked increase in the number of students from outside the EU/EEA. The average increase for the period at Finnish HE institutions was $118 \%$. Table 2 also shows that the polytechnics in particular contributed to the overall trend in both categories of students.

\subsubsection{The scholarship system}

It is a condition for inclusion in the pilot project that the institutions also offer scholarships to students. This means that the institutions themselves, rather than the state, run the scholarship system. The study 
found a big difference in how the universities fund these scholarships. Some have tied the programmes to Erasmus Mundus and fund their scholarships in the same way. Other universities fund their scholarships from external sources, e.g. company grants, or from their own financial resources at faculty level:

"Money [for scholarships] comes mainly from companies. But faculties can also use their "own" money to pay scholarships (not the budget money from the Ministry of Education)." (Representative, Finnish university)

In Finland, therefore, sources of scholarships vary depending on whether the universities have tied their study programmes to an international programme and on their ability to procure other sources of funding.

The study also found that scholarships are usually tied to the student's academic performance:

\footnotetext{
"We don't have a nationwide grant system - the universities have their own. There are huge differences between the universities, in terms of how much they support the students. And this depends on their academic performance." (Representative, Finnish university)
}

Examples of the universities' practices when it comes to awarding scholarships are given in the quotes below. They exemplify how the scholarships are allocated by the universities:

"We have 50 students who are enrolled in one of the three programmes where we collect tuition fees. Twenty of these students receive scholarships from us. Six of the scholarships cover tuition fees and living expenses, while the other 14 are for tuition fees only. The scholarships are awarded on academic criteria. Those that include living expenses also take the student's financial situation into account." (Representative, Finnish university)

"There are currently 34 students [who are subject to tuition fees]. Of these, eight receive the highest Aalto University scholarship. The scholarship covers the tuition fee for two years and includes €8,000 per year for living expenses and study costs. Fifteen students receive a scholarship that covers the tuition fee, while eight students receive scholarships that cover half of the tuition fee. One student pays the tuition fee in its entirety." (Official statement, Aalto University)

The Finnish system allows the universities to determine how any financial surplus earned from fees is spent. They are not obliged to reinvest any surplus in scholarships or free places. As Finnish practice is in its initial phase, it has only been possible to obtain limited information about how the universities have used any surpluses generated, but the example below shows that some universities actively use them in scholarships and programme development: 
"We will use any surplus generated from tuition fees for new scholarships and programme development. At this point, the programmes decide for themselves if they want to use a surplus for scholarships and/or programme development." (Representative, Finnish university)

The study concludes that the rules governing the pilot project, combined with the way in which the universities have implemented their scholarship systems, have helped to ensure that a significant proportion of international students from non-EU/EEA countries are able to study in Finland without paying fees. In the example of Aalto University, only one student from a non-EU/EEA country pays for the full programme. The remaining students receive some form of scholarship to help meet the costs of their education and other living expenses.

\subsection{Tuition fees in Norway}

In Norway, students generally do not pay tuition fees for higher education. This applies to Norwegian students and to international students from within and outside the EU/EEA. The Norwegian system is designed so that everyone has an equal opportunity to study at higher education level in the country, provided they meet the academic requirements. ${ }^{19}$

The fact that Norwegian HE is free for all is a result of political consensus. There is also broad political consensus that the HE sector adds value to the country. For now, politicians have no wish to make any changes. They believe higher education should be available to all, and they are aware that the Norwegian economy facilitates this. ${ }^{20}$

However, stakeholders in the Norwegian HE sector suggest that, due to developments elsewhere in the Region, free education for all may come under pressure within the next five to ten years. This is due to developments in the HE sector in the Nordic countries. These stakeholders think that the fact that the Nordic HE model varies from country to country could have negative consequences for Norway in future. These consequences could include a significant increase in the number of international students and therefore fewer opportunities for Norwegian students on HE programmes:

\footnotetext{
"If more and more international students keep coming here, something may have to happen. It's hard to tell. But it is clear that if we find ourselves in a situation where Norwegian students are unable to find places on HE courses due to international students, then this would of course increase the incentive to introduce tuition fees." (Representative, Norwegian university)
}

\footnotetext{
${ }^{19}$ Act relating to universities and university colleges (universitets- og høyskoleloven), Section 7.1.

20 Interview with Norwegian representative.
} 
The fact is that, in 2012, Norway still has - and is satisfied with - a system in which access to education is based on students' academic competences - not their financial wherewithal.

\subsubsection{Number of students at universities and university colleges (høyskoler)}

The Norwegian HE system consists of universities, scientific colleges 21 and university colleges. ${ }^{22}$ Norway also has a relatively well-developed sector of private educational institutions that offer programmes for Norwegian and international students. These institutions are eligible to apply for state grants to fund their operations. ${ }^{23}$ Overall, Norway has eight universities, nine scientific colleges (including three private ones) and 51 university colleges ( 24 of which are private).

The total number of HE students in Norway in 2012 was 203,500. This figure is divided between the types of institution as follows: universities approximately 45\%; scientific colleges $13 \%$; and university colleges $42 \%$. Overall, private HE institutions accounted for $14 \%$ of all HE students in Norway in 2012. The BI business school in Oslo accounted for the majority share $(60 \%)$ of all private students in the country. All students at BI pay approximately $€ 4,000$ per semester in tuition fees.

The trend in Norway is that there are increasing numbers of students at $\mathrm{HE}$ institutions. In the period 2005-2012, the number rose by $11 \%$. Table 3 shows the number of international students in Norway in the period 2005-2012.

Table 3: Number of international students in Norway

\begin{tabular}{lrrr}
\hline Students & $\mathbf{2 0 0 5}$ & $\mathbf{2 0 1 2 2 4}$ & \% change \\
\hline EU/EEA total & $\mathbf{4 , 6 0 4}$ & $\mathbf{8 , 7 1 0}$ & $+\mathbf{8 9 \%}$ \\
Universities & $(3,089)$ & $(4,930)$ & $(+60 \%)$ \\
Scientific Colleges & $(299)$ & $(1,244)$ & $(+316 \%)$ \\
University colleges & $(1,216)$ & $(2,536)$ & $(+109 \%)$ \\
Non-EU/EEA total & $\mathbf{5 , 6 2 1}$ & $\mathbf{7 , 2 5 8}$ & $+\mathbf{2 9 \%}$ \\
Universities & $(3,672)$ & $(4,687)$ & $(+28 \%)$ \\
Scientific Colleges & $(170)$ & $(924)$ & $(+444 \%)$ \\
University colleges & $(1,779)$ & $(1,647)$ & $(-7 \%)$ \\
Total & 10,225 & 15,968 & $+56 \%$ \\
\hline
\end{tabular}

Source: http://dbh.nsd.uib.no/. Note: Since Norway does not generate statistics solely for EU students, the data is for all European countries.

\footnotetext{
21 For example, the Norwegian Business School.

22 Institutions offering programmes from BA level upwards.

${ }^{23}$ Act relating to universities and university colleges (universitets- og høyskoleloven), Section 8.3.

24 Norwegian data is collated per semester, which is why spring semester 2012 is included. Source: Dbh.
} 
Table 3 shows a marked increase in the proportion of international students -both EU/EEA and non-EU/EEA - at universities and scientific colleges in Norway from 2005 to 2012. In 2012, there were 56\% more international students enrolled at Norwegian HE institutions than in 2005. At university level, the increase is mainly due to EU/EEA students $(+60 \%$ as opposed to $28 \%$ non-EU/EEA). A similar trend is visible in the scientific colleges, which experienced a significant increase in the number of both types of international student in the period 2005-2012. In addition, the number of international students in private institutions has increased significantly. The scientific colleges are primarily responsible for this increase. Again, the upward trend applies to students from both within and outside the EU/EEA.

\subsubsection{The scholarship system}

In Norway, there is generally no need for scholarships for public-sector $\mathrm{HE}$, since education is free.

In the private sector, the institution itself defines the nature of scholarships for international students and the criteria for awarding them. For example, at BI in Oslo, 20 students per year receive a scholarship that includes free schooling. Half of these students are Norwegian, but the rest are international students (from both Europe and the rest of the world). The criteria for awarding scholarships are academically based in other words, the students with the best academic competences receive the scholarships.

\subsection{Tuition fees in Iceland}

In Iceland, students generally do not pay tuition fees for higher education. According to the law governing higher education in Iceland, access to the state universities should be free for Icelandic as well as international students. ${ }^{25}$ The exception to this is that all students must pay an annual administration fee of approximately €350. ${ }^{26}$ This fee is set at a fixed rate across all HE institutions, but it varies over time, e.g. it went up from $€ 270$ in 2011 to $€ 350$ in 2012 due to rising costs.

The key movers behind the introduction of the fee in Iceland were the universities. The rationale was that such a fee would bind students financially to their study programme, and therefore strengthen their commitment. ${ }^{27}$

\footnotetext{
${ }^{25} \mathrm{http}: / /$ www.studyineurope.eu/study-in-iceland/admission/tuition-fees

${ }^{26}$ See, for example https://english.hi.is/university/international_students_0

${ }^{27}$ Interview with an Icelandic representative.
} 
The Icelandic universities report that they have felt the consequences of the introduction of tuition fees in the other Nordic countries, e.g. Denmark and Sweden. They have attracted more international students - including particular types:

\begin{abstract}
"When Denmark and Sweden introduced tuition fees, we noticed a significant increase in the number of international students. At the same time, we have seen a shift in the type of international students applying to study at our university. There are more from the developing countries who cannot afford to study in countries with tuition fees." (Representative, Icelandic university)
\end{abstract}

The Icelandic universities therefore introduced the administration fee to help reduce their costs pertaining to international students. At the same time, there have been changes in both the number and type of international students in Iceland over the last few years.

\title{
Number of students in universities (háskóli)
}

In Iceland, HE institutions are called háskóli. These institutions are generally referred to as universities and run programmes at Master's and $\mathrm{PhD}$ level, as well as Bachelor level. In the other Nordic countries, the latter are run separately by, for example, colleges or Universities of Applied Sciences.

The HE system in Iceland is organised by the public sector, while private universities receive grants. There are a total of seven universities four state-run, three private. The private ones charge tuition fees according to whether the students are from within or outside the EU/EEA. The rates range from $€ 1,800$ to $€ 3,600$ p.a. for EU/EEA students, and $€ 6,000$ to $€ 9,000$ p.a. for non-EU/EEA students. 28

The general trend in Iceland is for an increasing number of HE students - up 17\% in the period 2005-2010. In 2010, there were in total 18,391 students, of whom 1,133 (6\%) were international students. The number of international students has increased by $54 \%$ in the period 2005-2010 (see Table 4).

Table 4: Number of international students in Iceland

\begin{tabular}{lccc}
\hline Table 4: Number of international students in Iceland & $\mathbf{2 0 0 5}$ & $\mathbf{2 0 1 0}$ & \% change \\
\hline EU/EEA total & 586 & 852 & $+45 \%$ \\
Non-EU/EEA total & 149 & 281 & $+86 \%$ \\
Total & 735 & 1,133 & $+54 \%$ \\
\hline
\end{tabular}

Source: Statistics Iceland.

\footnotetext{
${ }^{28}$ In principle, private universities are free to determine their own fee rates. In practice, however, they are around this level, regardless of whether students are from the EU/EEA or not.
} 
The above figures show a general increase in the number of international students in Iceland between 2005 and 2010. The increase consists of EU/EEA students, which nominally constituted the largest group in both 2005 and 2010. However, in percentage terms, the biggest increase was in the number of non-EU/EEA students (86\%). The trend is for general growth in international student numbers in Iceland - and the rate of growth is significantly higher than for general growth in the number of students, which was $17 \%$ in $2005-2010$.

This trend suggests that the admin fee has not had a negative impact on the number of international students. The Icelandic universities concur, noting that the fee has also reduced the cost of administrative work at the same time:

"It is good to see that we still have many international students even though we have raised the administration fee. It shows that international students do not consider the fee a barrier to studying here." (Representative, Icelandic university)

\subsubsection{The scholarship system}

Scholarships are administered by the state in Iceland. Each year, the Ministry of Education, Science and Culture awards a number of scholarships to international students. In the period 1 September 2012 to 30 April 2013, 18 scholarships were awarded to international students from both within and outside of the EU/EEA.

\subsection{Tuition fees in Denmark}

In 2005, the Danish Parliament decided that, from 1 August 2006, international students from outside the EU/EEA ${ }^{29}$ must pay full tuition fees for higher education in Denmark. ${ }^{30}$ Denmark became the first Nordic country to charge fees to non-EU/EEA students. One of the arguments for introducing tuition fees in Denmark was to avoid "...third countries sending students to Danish universities with a view to the Danish government paying for their education in whole or in part."31 The law also aimed to enable institutions to attract the best-qualified students from third countries to Danish Master's programmes via a scheme offering scholarships and free places. ${ }^{32}$

\footnotetext{
${ }^{29}$ Students from Switzerland were also exempted from this rule from academic year 2009/2010.

30 This did not come into force until 1 January 2008 for study programmes in areas governed by the Ministry of Culture.

31 Bill L114, explanatory memorandum 2.3.

32 Except, however, artistic and cultural study programmes under the Ministry of Culture, which were not covered by the scheme for free places and scholarships until 2011.
} 
The Danish HE system consists of universities, other HE institutions, university colleges and business academies. The universities run programmes at $\mathrm{PhD}$, Master's and Bachelor level, while the university colleges run programmes up to Bachelor level. ${ }^{33}$ Other Danish HE institutions run programmes up to Master's level but do not have university titles, e.g. the School of Architecture and the Academy of Music.

The globalisation agenda has impacted significantly on Danish university policy. To equip the universities to deliver research, study programmes and knowledge transfer that meet the highest international standards, the Danish universities and research sector has undergone comprehensive reform: the universities' dynamism and scope for action have been increased by the introduction of boards with a majority of external members and appointed executive management, ${ }^{34}$ the sector has been consolidated into fewer and stronger institutions ${ }^{35}$ and there has been marked growth in state investment. ${ }^{36}$

Over the past decade, Danish university policy has been a work in progress, comprising two strands. On the one hand, the universities have a social obligation to help more young people complete an education. On the other, the Danish universities must be internationally competitive which includes attracting talented and qualified students. The introduction of tuition fees for non-EU/EEA students should be seen in this light.

\subsubsection{Implementation of the legislation}

The Danish tuition-fee model devolves responsibility for administration and pricing to the individual universities. This authority to price their own programmes is subject to the general principle that the price should correspond to the cost of the programme. According to the legislation, universities must therefore establish a basis for calculating the price of individual programmes. In practice, this means that the price of a programme is, as a minimum, equal to the grant that the university receives from the Danish state. ${ }^{37}$

A university is entitled to set a tuition fee that is higher than its costs, in which case the surplus can be used to fund scholarships, free places, etc. ${ }^{38}$ Danish universities have chosen different methods of administrating tuition fees, and there are differences between them in terms of the de-

\footnotetext{
33 Equivalent in English to "Universities of Applied Sciences."

34 The University Reform, 2003.

35 In 2007, several universities and sectoral research institutions merged. Twenty-five research institutions merged into eight universities (which now conduct the vast majority of publicly funded research) and three sectoral research institutes.

36 Growth Forum (2011): International competitive universities.

${ }^{37}$ Also known as the taximeter rate for the programme concerned.

${ }^{38}$ The same applies to university colleges and teacher-training programmes.
} 
gree of centralisation or decentralisation of decision-making powers. They also use different pricing strategies. Table 5 shows university tuition fees in Denmark. The price per programme, the authority to set the price and whether or not an application fee is charged all vary, with prices of up to twice the taximeter rate. In this context, the term "decentralised" means that the universities have delegated the decision-making powers, etc. to their faculties. "Centralised" means that the universities take the decision centrally, and the faculties then implement this decision.

Table 5: Tuition fees in Danish universities ${ }^{39}$

\begin{tabular}{|c|c|c|c|c|c|c|c|c|}
\hline Variable & AAU & $A U$ & SDU & KU & DTU & RUC & CBS & ITU \\
\hline Price & $\begin{array}{l}\text { Min. } 1 \mathrm{x} \\
\text { taximeter }\end{array}$ & $\begin{array}{l}\text { Min. } 1 \mathrm{x} \\
\text { taximeter }\end{array}$ & $\begin{array}{l}1 \mathrm{x} \\
\text { taximeter }\end{array}$ & $\begin{array}{l}1-2 \mathrm{x} \\
\text { taximeter }\end{array}$ & $\begin{array}{l}\text { Min. } 1 \mathrm{x} \\
\text { taximeter }\end{array}$ & $\begin{array}{l}\text { Min. } 1 \mathrm{x} \\
\text { taximeter }\end{array}$ & $\begin{array}{l}\text { Min. } 1 \mathrm{x} \\
\text { taximeter }\end{array}$ & $\begin{array}{l}1 \mathrm{x} \\
\text { taximeter }\end{array}$ \\
\hline $\begin{array}{l}\text { Decision- } \\
\text { making } \\
\text { level }\end{array}$ & $\begin{array}{l}\text { Decen- } \\
\text { tralised }\end{array}$ & $\begin{array}{l}\text { Centra- } \\
\text { lised }\end{array}$ & $\begin{array}{l}\text { Centra- } \\
\text { lised }\end{array}$ & $\begin{array}{l}\text { Decen- } \\
\text { tralised }\end{array}$ & $\begin{array}{l}\text { Centra- } \\
\text { lised }\end{array}$ & $\begin{array}{l}\text { Centra- } \\
\text { lised }\end{array}$ & $\begin{array}{l}\text { Centra- } \\
\text { lised }\end{array}$ & $\begin{array}{l}\text { Centra- } \\
\text { lised }\end{array}$ \\
\hline $\begin{array}{l}\text { Applica- } \\
\text { tion fee }\end{array}$ & $\begin{array}{l}\text { Yes } \\
(€ 105)\end{array}$ & No & No & No & No & $\begin{array}{l}\text { Yes } \\
(€ 150)\end{array}$ & $\begin{array}{l}\text { Yes } \\
(€ 150)\end{array}$ & No \\
\hline
\end{tabular}

Source: Oxford Research 2012.

The University of Copenhagen has decentralised pricing to faculty level, and the faculties are also responsible for marketing their programmes. The prices of programmes at UCPH range from the minimum taximeter rate to double the taximeter rate, and the reasons for this are equally varied:

"It varies depending on how the faculties set the price and what strategies and rationales are behind the decisions." (Representative, University of Copenhagen)

DTU has opted for centralised pricing, i.e. the taximeter rate for all programmes, while the Board at Aarhus University makes decisions based on recommendations from the individual faculties. CBS is different. Here, the fee paid by international students from outside the EU/EEA is at a level above the taximeter rate. This strategy is quite deliberate:

"We set the price at above the taximeter rate quite deliberately because we are not interested in our programmes being priced too cheaply in an international context." (Representative, Copenhagen Business School)

Since the pricing of the individual programmes reflects the taximeter rate, social sciences and humanities (typical rate $€ 6,000$ ) are the cheap-

\footnotetext{
${ }^{39}$ Aalborg University (AAU), Aarhus University (AU), University of Southern Den mark (SDU), University of Copenhagen (UCPH), Technical University of Denmark (DTU), Roskilde University (RUC), Copenhagen Business School (CBS), IT University of Copenhagen (ITU).
} 
est, while the technical, science and medical programmes are generally more expensive (typical rate $€ 13,000$ ). 40

For other HE programmes in Denmark - at university colleges, business academies and other HE institutions - the institution generally prices the programmes at min. the taximeter rate. ${ }^{41} \mathrm{In}$ general, it is up to the institutions themselves to set the price level for their programmes. For certain programmes, other HE institutions also charge a fee for entrance examinations, but this is generally not the case at university colleges and business academies.

\subsubsection{Number of students at universities, etc.}

Denmark has eight universities, 14 other HE institutions, 11 university colleges and 11 business academies.

In 2010, the number of HE students in Denmark was 201,417,42 divided between the respective types of institutions as follows: universities approximately 66\%; other HE institutions 1\%; and university colleges and business academies together form the remaining 33\%.

HE student numbers are rising in Denmark. The total increased by $11 \%$ in the period 2005-2010. Table 6 provides details of international students in Denmark, 2005-2010.

Table 6: Number of international students in Denmark 2005-2010

\begin{tabular}{lrrr}
\hline Students & $\mathbf{2 0 0 5}$ & $\mathbf{2 0 1 0}$ & \% change \\
\hline EU/EEA total & $\mathbf{5 , 3 6 7}$ & $\mathbf{1 3 , 6 2 1}$ & $\mathbf{+ 1 5 4 \%}$ \\
Universities & $(3,626)$ & $(8,454)$ & $+133 \%$ \\
Other HE institutions & $(367)$ & $(614)$ & $+67 \%$ \\
University colleges & $(1,000)$ & $(2,603)$ & $+160 \%$ \\
Business academies & $(374)$ & $(1,950)$ & $+421 \%$ \\
Non-EU/EEA total & $\mathbf{2 , 7 3 7}$ & $\mathbf{2 , 8 6 2}$ & $\mathbf{+ 5 \%}$ \\
Universities & $(2,189)$ & $(1,510)$ & $-31 \%$ \\
Other HE institutions & $(20)$ & $(33)$ & $65 \%$ \\
University colleges & $(439)$ & $(406)$ & $-8 \%$ \\
Business academies & $(593)$ & $(913)$ & $+54 \%$ \\
Total & 8,104 & 16,483 & $+103 \%$ \\
Total (incl. unknown) & 9,614 & 17,589 & $+83 \%$ \\
\hline
\end{tabular}

NOTE: This table includes only students doing whole study programmes in Denmark, i.e. not short exchange programmes.

Source: the Danish Agency for Universities and Internationalisation, and the Ministry of Culture's Education Statistics. 
Table 6 shows a general increase in the number of international students in Denmark. From 2005 to 2010, the number rose by 103\%. The table also identifies two trends: firstly, that the number of international students from EU/EEA countries increased significantly between 2005 and 2010 $(+154 \%)$. This is true across all types of programmes, but university colleges and business academies had the greatest percentage increases, universities the biggest increase in nominal terms. Secondly, the number of international students from countries outside the EU/EEA has been relatively consistent between 2005 and 2010, primarily due to a significant decline in the numbers of such students at universities $(-31 \%)$ being offset by a significant increase $(+54 \%)$ at the business academies. 43

\subsubsection{The scholarship system}

For international students from outside the EU/EEA, the Danish state provides funding for free places and scholarships in universities, university colleges and business academies, ${ }^{44}$ as well as development scholarships via DANIDA.

The state has a pool of funding that it allocates to the universities, who redistribute it in the form of scholarships ${ }^{45}$ covering full or part programmes. Since fees were introduced, the pool for scholarships for these university students has increased from approx. DKK 2 million in 2006 to over DKK 28.7 million in 2009 and to DKK 59 million in 2011.46 In the field of vocational training and university colleges, grants for free places and scholarships have increased from approx. DKK 1 million in 2006 to over DKK 14 million in 2007 and to approx. DKK 20 million in 2011. Other institutions of higher education do not have a scholarship scheme for non-EU/EEA students. The allocation of funding to scholarships and free places in HE has therefore increased significantly since the introduction of tuition fees for non-EU/EEA students in 2006.

The study concludes that Danish universities consider that there is too little funding for scholarships for non-EU/EEA students. According to these stakeholders, this is problematic because it impedes their ability to attract the best students from outside the EU/EEA. The Danish universities find it difficult to compete internationally, as universities in other European countries receive direct support from the state - including for non-EU/EEA students. Non-EU/EEA students in these countries therefore pay a smaller share of the universities' programme costs.

\footnotetext{
${ }^{43}$ Note here that tuition fees for these types of programmes were not introduced until 1 January 2008. ${ }^{44} \mathrm{FL} \S 19.2$ and $\S 19.83 .02$ (prev. $\S 20.98 .61$ ).

45 The same is true of university colleges and business academies. Since $1 / 2 / 2010$, these institutions have had the power to make independent decisions about awarding funds for scholarships and free places. 46 The Finance Act 2009, § 19.25.13.70 and the State Budget 2012, § 19.22 \& 20.98.61. The increase in the university sector from 2009 to 2011 was due to Globalisation Funding.
} 
Over time, the universities have experimented with different scholarships and free-place schemes, e.g. free places with a small amount for living expenses or free places with full living expenses covered. ${ }^{47}$ This is possible because the universities have the power to decide how they will allocate the state money they receive. Aarhus University, for instance, has identified benefits in providing a free place and full living costs, because non-EU/EEA students have difficulty getting a student job in Denmark. In 2009, Aalborg University decided to introduce a model that offered free places but did not cover living expenses. However, this system had its drawbacks:

\footnotetext{
"Our experience of offering scholarships without living expenses for certain types of students has not been entirely positive. Of course, it is good that we can now offer scholarships to more students, but African students in particular find it very difficult to support themselves." (Representative, Aalborg University)
}

The awarding of scholarships generally depends on the student's academic performance, whereas individual scholarships that also cover living expenses are allocated according to financial need.

The study shows that the scholarships awarded by Danish universities are primarily funded from state grants. To a limited extent, some universities have managed to supplement these by establishing additional scholarships, funded by external companies or foundations. At some universities these scholarships are five to six times larger than full scholarships. ${ }^{48}$ This is not a widespread practice.

Danish legislation states that any surplus generated from tuition fees can be used to develop the programme or transferred to free places or scholarships for future non-EU/EEA students. ${ }^{49}$ However, it is not a specific legal requirement that any surplus is used for this purpose - and the interviews with the universities do not indicate that this practice is widespread. It is more common for tuition fees to be set close to the taximeter rate, and therefore only a limited surplus is generated, if any at all. Any surplus is used primarily for the extra administration associated with tuition fees:

"In the University, "tuition" for students from outside the EU/EEA is set pretty close to the taximeter level. We do not generate a surplus from students from third countries, as the difference between tuition fees for them and the taximeter, which we get for Danish/EU/EEA students, is used for the extra costs of screening, receiving and advising international students." (Representative, Danish university)

\footnotetext{
47 The amount varies from $€ 6,000$ to $€ 16,000$. http://studyindenmark.dk/study-in-denmark/tuition-feesand-scholarships

48 See Oxford Research's interviews with representatives from the international offices at Danish universities. ${ }^{49}$ https://www.retsinformation.dk/Forms/R0710.aspx?id=100435
} 
The study found that non-EU/EEA students at HE institutions in Denmark generally have the opportunity to receive scholarships from either the Danish state or the HE institutions themselves. At the same time, the study also found that the universities in particular consider that the lack of this kind of state scholarship for these categories of international students only serves to make it harder to compete with other European universities. They would like to see more state scholarships for nonEU/EEA students.

\subsection{Tuition fees in Sweden}

In April 2010, the Swedish Parliament decided that students from outside the EU/EEA must pay both an application fee and tuition fees to higher education institutions from the 2011 autumn semester onwards. 50

The underlying rationale was very similar to the Danish reasoning from 2006. It was argued, firstly, that the Swedish education system must, first and foremost, meet the demand for higher education among the citizens of Sweden. Secondly, that the universities in Sweden must compete on equal terms with universities in other countries and attract students on the basis of a good study environment and high academic standards - not on the basis of an offer of free education.

As part of the package supporting the introduction of tuition fees, a series of measures were also introduced, the aims of which were to strengthen Sweden's competitive position in the education market and to compensate for the administrative costs caused by the introduction of fees:

In Sweden, the individual educational institution is responsible for informing prospective students about the study opportunities it offers, while the government institution the Swedish Institute is responsible for marketing Sweden in an educational context. As part of the fees reform, the fixed grant to the Swedish Institute for promoting Sweden as a study destination increased from SEK 3 million to SEK 5 million p.a.

A universal application fee of SEK 900 has also been introduced. This fee is intended to discourage large numbers of speculative applications and to compensate for the administrative costs for universities and colleges associated with the implementation of tuition fees. The fee is paid by international non-EU/EEA students.

As part of the reform, new scholarships for international students have been introduced. In total, SEK 160 million has been earmarked for students from countries outside the EU/EEA.

${ }^{50}$ Also including Switzerland. The decision was part of the Bill "Compete with quality - tuition fees for international students' (prop. 2009/10:65). 


\subsubsection{Implementation of the legislation}

Universities and colleges in Sweden decide the size of tuition fees for individual programmes. The legislation stipulates that the fee covers the full costs. This has given rise to some uncertainty, as it has not been clear how full costs should be interpreted - and whether, for example, indirect costs ${ }^{51}$ associated with the reform should be included in the price of a programme.

In addition, the Association of Swedish Higher Education (SUHF), 52 which represents 40 universities and colleges, has called for greater flexibility in relation to the size of tuition and application fees. The application fee is fixed and compulsory. The requirement for full recovery of costs means that there is, in effect, a minimum price per programme. SUHF wants the universities to have greater flexibility so that they can deploy prices more strategically and competitively. By making active use of their ability to set prices, they will be able to identify demand and tailor the ways in which they market themselves in various subject areas.

The study also found out that institutions associate a heavy administrative burden with implementing the reform. Universities and colleges feel that they have expended considerable resources on implementation. Enrolment work is particularly significant in this context, because the assumption is that all applicants from outside the EU/EEA are paying students, and must therefore prove that they are eligible for any exemption from the fee. ${ }^{33}$ However, it is the stakeholders' experience that these are teething problems, which were exacerbated by the relatively short timeframe in which the reform was implemented.

Swedish tuition-fee legislation stipulates that the educational institutions themselves retain the income from the fees from non-EU/EEA students. ${ }^{54}$ As the system is still new, there is not yet a solid basis for determining how the revenues are being used. However, a preliminary examination of practice shows that, in the short term, it is not the finances that are attractive to institutions, but the internationalisation of study programmes:

"Realistically, I think tuition fees will only ever be an important source of income for a very few institutions - maybe only three to five. The incentive to attract students from outside the EU/EEA is internationalisation. It is not a financial incentive." (Representative, Swedish university)

\footnotetext{
51 E.g. for marketing and additional administrative work.

52 The Association of Swedish Higher Education; http://www.suhf.se/

53 Swedish National Agency for Higher Education (2011 12 R): "The fees reform - first impressions."

54 Prop. 2009/10: 65, section 6.3.
} 


\subsubsection{Number of students at universities and colleges}

The Swedish HE system consists of universities and colleges.

There are a total of 51 colleges and universities offering academic programmes in Sweden. Of these, 14 are state universities and 20 are state colleges. There are also 17 other providers of higher education. Three of these, Chalmers University of Technology AB, Jönköping University and the Stockholm School of Economics, have the authority to educate students up to $\mathrm{PhD}$ level. The remainder are allowed to offer programmes up to Bachelor and Master's level. Four of the institutions only train psychotherapists.

In 2010, the number of students studying in the HE sector in Sweden was 441,600 . The number of HE students has increased every year since 2006 , when the number was 380,100 . The number of students at HE institutions increased by $16 \%$ from 2006 to 2010.55

Table 7 shows the trend in the number of international students in Sweden, 2006-2010.

Table 7: Number of international students in Sweden ${ }^{56}$

\begin{tabular}{lrrr}
\hline Students & $\mathbf{2 0 0 6}$ & $\mathbf{2 0 1 0}$ & \% change \\
\hline EU/EEA total & $\mathbf{4 , 4 9 7}$ & $\mathbf{5 , 8 4 6}$ & $\mathbf{+ 3 3 \%}$ \\
Universities and collages with PhD programmes & $(4,137)$ & $(5,413)$ & $(+31 \%)$ \\
Colleges with basic and advanced level & $(360)$ & $(433)$ & $(+20 \%)$ \\
Non-EU/EEA total & $\mathbf{7 , 3 0 0}$ & $\mathbf{2 2 , 0 1 3}$ & $\mathbf{2 0 2 \%}$ \\
Universities and collages with PhD programmes & $(6,835)$ & $(20,760)$ & $(+204 \%)$ \\
Colleges with basic and advanced level & $(465)$ & $(1,253)$ & $(+169 \%)$ \\
Total & 11,797 & 27,859 & $+136 \%$ \\
\hline
\end{tabular}

Source: HSV and SCB's statistics on international mobility:

http://www.hsv.se/statistik/statistikomhogskolan/. Note that the number covers both students taking individual courses and students taking whole programmes. It has not been possible to obtain more differentiated data in this field.

Table 7 shows that the overall number of international students in Sweden increased between 2006 and 2010. This was primarily driven by a significant rise in the number of non-EU/EEA students (202\%), while the number of EU/EEA students has not increased as much (33\%). In percentage terms, there have been increases in the numbers of international students at both universities and colleges, but it is the number of non-EU/EEA students at universities that saw the biggest rise during the period (204\%).

\footnotetext{
55 The Swedish National Agency for Higher Education and Statistics Sweden (2012): UF 20 SM 1202 “Universities and colleges - students and exams at basic and advanced level 2010/11', p.17.

56 The years 2006 and 2010 denote the academic years 2006/2007 and 2010/2011.
} 


\subsubsection{The scholarship system}

In the Swedish HE context, scholarships are an important tool in global competition. As a result of the introduction of tuition fees for nonEU/EEA students, two scholarship systems have been introduced: the Swedish Institute Study Scholarships and the Swedish Tuition Fee Scholarship.

The Swedish Institute awards its Study Scholarships to highly qualified students from countries with which Sweden has a long-term development co-operation. ${ }^{57}$ The funds can be used for both tuition fees and living expenses. Approximately 120 scholarships are awarded per academic year under this scheme. In addition, a portion of the funds is allocated to scholarships for students from developing countries. ${ }^{58}$

The Swedish Tuition Fee Scholarships target qualified students from countries outside the EU/EEA. A state body, the International Programme Office for Education and Training, allocates the funds to the educational institutions, which then distribute them to the students. This is done by means of a sliding scale, based on the number of international students that the individual university has accepted in the past. The universities and colleges themselves decide whether the funds will be earmarked for full scholarships to a few students or, for example, halfscholarships to a larger number of students. The funds can only be used to cover tuition fees, not living expenses.

Scholarship schemes in Sweden have been upgraded as a result of the introduction of tuition fees for non-EU/EEA students. In addition, the system has been set up in such a way as to differentiate between two types of awards: one targeting specific countries, the other delegated to the universities, which allocate funds as they see fit.

The scholarship system is also designed to encourage HE providers to introduce their own scholarships, thereby strengthening Sweden's competitive position when it comes to attracting the best students. According to several education-related stakeholders, however, this is proving difficult to achieve. Only very few educational institutions have business partners that have sponsored these scholarships:

"It will be difficult to get the system up and running outside of the state. Only a few institutions currently have close contacts with the business community in relation to scholarships, and I think it will be marginal how much funding can be procured." (Swedish stakeholder)

\footnotetext{
${ }^{57}$ Bangladesh, Bolivia, Burkina Faso, Cambodia, Ethiopia, Kenya, Mali, Mozambique, Rwanda, Tanzania, Uganda, and Zambia.

58 Developing countries in this context means the list of ODA countries, as defined by the OECD. See the list here: http://www.oecd.org/development/aidstatistics/48858205.pdf
} 
However, interviews with selected universities show that some of them are working actively to procure independent scholarships. For example, Lund University - the university in Sweden with the most international students - is working strategically with scholarships and has supplemented the government's scholarship programme for students from countries outside the EU/EEA with private funds. Following the introduction of student fees, Lund University has intensified work on scholarships, and has managed to attract a number of private donors. 


\section{Impact assessment}

This chapter describes the effect of the introduction of tuition fees, including both the direct effects in countries that have charged fees for some time (Denmark and Sweden) and the indirect consequences for the others (Iceland, Norway and Finland).

It is worth emphasising that, where it has been possible to obtain data, the impact assessment is based on numbers of non-EU/EEA students in the respective countries. Focusing on student intake provides a picture of the trend over several years. This helps to isolate the effects of the fees, since the student numbers ${ }^{59}$ will provide a current picture that may, for example be influenced by other factors such as study progression, drop-out rates, etc.

\subsection{Impact of tuition fees in the Nordic countries}

In considering the impact of the introduction of tuition fees in the Nordic Region, the data is restricted to Denmark and Sweden, as it is only in relation to these two countries that it is possible to comment specifically on the direct effect of fees on the numbers of non-EU/EEA students in the Region. Intake numbers for the other countries show the trend in student numbers over the same period in countries where no fees were charged.

This section shows that the effect of tuition fees on the number of non-EU/EEA students takes the form of a "modified" u-curve, i.e. the number of students falls when tuition fees are introduced, but rises again further down the line. Denmark is the prime example of this.

The number of students falls because the situation changes dramatically. For non-EU/EEA students, enrolling on a previously free programme now requires greater financial independence or a scholarship to study in Denmark (from autumn 2006) and Sweden (from autumn 2011). The number of students increases again, as seen in Denmark, partly because scholarships are offered, partly due to consolidation in the international market, and partly due to a greater effort in marketing the programmes abroad. The various explanations are considered in greater depth below. 
Figure 1 shows an index of the intake of non-EU/EEA students in the Nordic countries. Table 8 shows the nominal figures behind it. Norway is not included in Figure 1, because it has not been possible to obtain longitudinal data for it.

\section{Figure 1: Indexed intake of non-EU/EEA students}

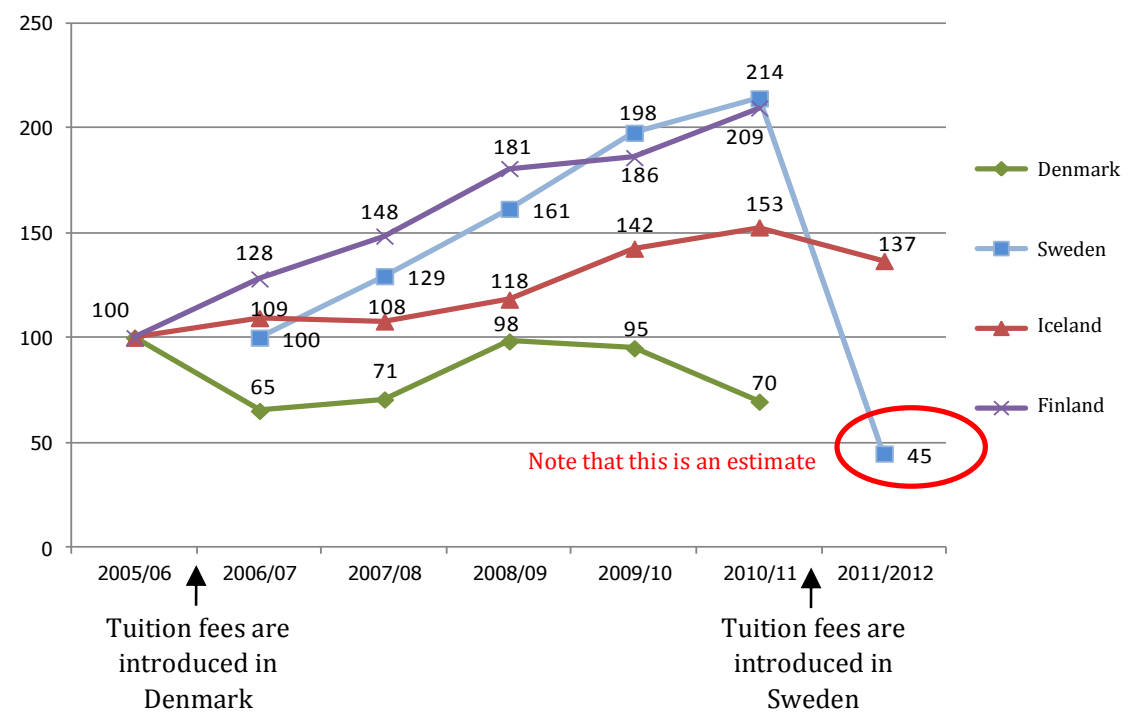

Her må I lige forklare, hvordan det skal side. Layouteren

Table 8: Number of non-EU/EEA students

\begin{tabular}{lrrrrrrr}
\hline Country & $\mathbf{2 0 0 5 / 0 6}$ & $\mathbf{2 0 0 6 / 0 7}$ & $\mathbf{2 0 0 7 / 0 8}$ & $\mathbf{2 0 0 8 / 0 9}$ & $\mathbf{2 0 0 9 / 1 0}$ & $\mathbf{2 0 1 0 / 1 1}$ & $\mathbf{2 0 1 1 / 2 0 1 2}$ \\
\hline Denmark* & 1,528 & 995 & 1,078 & 1,501 & 1,451 & 1,062 & \\
Sweden** & & 3,844 & 4,971 & 6,203 & 7,595 & 8,226 & 1,722 \\
Iceland*** & 375 & 410 & 404 & 443 & 534 & 572 & 512 \\
Finland**** & 1,672 & 2,140 & 2,481 & 3,019 & 3,106 & 3,501 & \\
\hline
\end{tabular}


*The data for Denmark is based on the ministry of Education's Mobility Statistics, which only includes foreign nationals taking a whole study programme in Denmark (either a Bachelor or Master's). It also only includes students who arrived in the country a maximum of one year before starting the study programme. This means that foreigners with permanent residence permits are excluded from the data.

**Data for Sweden is based on figures published by the Swedish National Agency for Higher Education and Statistics Sweden (SCB) in the publication "Internationell Universitet och högskolor. Internationell mobilitet i högskolan läsåret 2010/11" (International Universities and Colleges: International mobility, academic year 2010/11), Table 3A.

The data and index cover the total number of incoming free-mover students in the academic year at all Swedish universities and colleges. While the Danish data only includes students who take a full study programme in the country, the Swedes also count students who take individual courses. Data shows that $27 \%$ of all free-mover students take individual courses rather than whole study programmes. NB: the figures for academic year 2011/2012 are based on an estimate, as data is only available for autumn semester 2011 . The estimate is based on an assumption that the intake of students from countries outside the EU/EEA in the spring and autumn semesters will be the same in academic year $2011 / 2012$ as it was in 2010/2011. In autumn semester 2011,1,600 were registered, compared with 7,600 in autumn semester 2010. The reasonableness of this assumption is supported by the fact that the National Agency for Higher Education considers that "the overall pattern for the autumn term 2011 will continue for the academic year" (Swedish National Agency for Higher Education: (Statistical Analysis), 22/11/2011).

Note that both countries have a group of students whose country of origin could not be determined. The national studies assume that they are mainly EU/EEA students, as they do not require a residence permit nor information about their country of origin and residence status. However, they are presented as unknown in the national data and are not included in this report.

***The Icelandic data is based on data from Statistics Iceland. It identifies non-EU/EEA students enrolled on the international classification ISCED levels 5 and 6 , which covers universities, professional bachelor programmes, businessacademy programmes and $\mathrm{PhDs}$.

****The data for Finland is based on data from the Finnish Ministry of Education and Culture and covers the intake of non-EU/EEA students to university programmes and polytechnics.

Figure 1 shows that the Danish index falls from 100 in 2005 to 65 in 2006 (the academic year in which fees were introduced). The number then increases again. In academic years 2008 and 2009, where the intake index is 98 and 95 , respectively, the figure rapidly approaches the pre-fee index of 100 . There is, therefore, a modified u-curve, in which the number of non-EU/EEA students falls as a consequence of the introduc- 
tion of tuition fees and then rises again. However, between 2009 and 2010, there is still a decline in the number of non-EU/EEA students in Denmark. This might be attributed to a drop in the number of nonEU/EEA students on business-academy programmes, triggered by stricter rules about subsidies for foreign students.

In Sweden, the figures show a steady increase from 2006 to 2010 in the intake of non-EU/EEA students. With the introduction of tuition fees in academic year 2011,60 there is a fall in the index from 100 to 21 . With the proviso that an estimate is included, the Swedish data shows that the fall was greater than in Denmark.

Based on Denmark's experience, the Swedes were conscious of the fact that the introduction of fees would lead to a reduction in the number of students from countries outside the EU/EEA. The hope is that, as with Denmark, the numbers will rise again relatively quickly. However, stakeholders are conscious that it will be difficult to attain pre-fee levels:

"We have set a target of $50 \%$ of the number we were at before the introduction of fees within three years. It's more realistic. We won't be back to $100 \%$."

(Representative, Swedish university)

There has not been a return to the pre-2011 numbers of non-EU/EEA students at Swedish universities, but rather steady growth that, within a two-year period, looks set to reach around $50 \%$ of the level before the fees were introduced.

In Iceland, the number of new non-EU/EEA students has been increasing since 2005, particularly in the period from 2008 to 2010. The Icelandic education system has undergone a process of internationalisation, which is reflected in the fact that international students represent an increasing proportion of total student numbers. International students now make up $6 \%$ of the total, compared with $4 \%$ in 2000.61

Icelandic stakeholders do not think that the registration fee represents a barrier to non-EU/EEA students, as it is set at such a low level. They do, however, point out that the introduction of tuition fees in Sweden - and particularly in Denmark - has led to more non-EU/EEA students coming to Iceland.

In Finland, the number of non-EU/EEA students has risen between 2005 and 2010 from index 100 to index 209. Fees for non-EU/EEA students are being piloted in a limited way from 2010 to 2014. The effects have been minimal so far.

Longitudinal data on the intake of non-EU/EEA students ${ }^{62}$ is not available for Norway, so it is not possible to identify year-on-year trends.

\footnotetext{
60 This is an estimate. Exact Swedish figures were not available.

61 Interview with an Icelandic representative.

62 Norwegian Social Science Data Services only has data for the intake of non-EU/EEA students in 2011/12.
} 
Instead, total numbers can be used to provide an indication of trends during the period in question. As shown in Chapter 1.2, the total number of non-EU/EEA students increased by 29\% between 2005 and 2011 . This indicates an increase in the intake of non-EU/EEA students during the same period. Stakeholders in Norway report that they have noticed an increase in the intake of non-EU/EEA students after the introduction of tuition fees in Denmark and Sweden. This could suggest that Norway attracted some of those who might otherwise have opted for Denmark.

\subsubsection{Number of paying non-EU/EEA students}

Extrapolating from the above, the question is what proportion of the non-EU/EEA students pay tuition fees and how many receive scholarships. As mentioned previously, when describing the rule changes, some students with a connection to the recipient country are exempt from tuition fees, and both Denmark and Sweden have set up scholarship schemes for students from outside the EU/EEA.

The Danish Ministry of Education's Mobility Statistics do not show the total number of non-EU/EEA students who pay or have free places. However, Universities Denmark, Statistics does show the split between non-EU/EEA students enrolled at universities who pay fees and those who do not. The figures show that $743(20 \%)$ out of 3,764 non-EU/EEA students enrolled at universities in Denmark ${ }^{63}$ paid to study in the country in 2011. In 2007, this figure was 7\%, and therefore the proportion of paying non-EU/EEA students at Danish universities has been rising. A partial explanation for the increase is the fact that students who were enrolled in 2007 but part of pre-autumn 2006 intake were not obliged to pay fees. Students in receipt of state scholarships are included in the non-paying group.

In Sweden, 1,150 students were subject to fees in 2011. This constitutes $72 \%$ of the total of 1,600 non-EU/EEA students registered for the autumn semester 2011. A recent questionnaire survey ${ }^{64}$ of Swedish universities and colleges shows that approximately $40 \%$ of new students who registered in autumn 2011 and were subject to fees received scholarships from the Swedish state, while the other $60 \%$, which corresponds to almost 500 students, paid their own way. It should be noted that the proportions in Sweden and Denmark are not comparable, as the Danish figures are for the number of registered students, while the Swedish

\footnotetext{
${ }^{63}$ According to Universities Denmark, this number includes students who pay their own way and are enrolled on ordinary full-time programmes, Master's or diploma programmes from countries outside the EU/EEA, as well as those on continuing education programmes, i.e. graduate programmes such as MBAs, diplomas, etc.

${ }^{64}$ Swedish National Agency for Higher Education (2011): “Avgiftreformen - lärosätanes förste erfarenheter "(The fees reform - first impressions).
} 
data is for the number of new registered students at the first intake after the introduction of tuition fees. 65

\subsubsection{Economic consequences}

In Denmark, an important political rationale behind the introduction of tuition fees for non-EU/EEA students was to ensure that the costs of these students would be fully covered. The aim was to reduce the cost to the Danish state of providing non-EU/EEA students with a free education. It is, therefore, a condition that HE programmes, as a minimum, are priced according to the current taximeter rate. This matches the state's costs, as calculated by the taximeter, and creates a budget saving. This saving is then offset by an additional cost for scholarships, which means that the introduction of tuition fees is ultimately cost-neutral. 66

The pricing rules regarding the minimum taximeter rate vary. For example, the university colleges and business academies are allowed to charge a fee that is below the taximeter level for a given programme, as long as its total revenue-raising activities balance out over a four-year period.67 Universities, university colleges and business academies are therefore required to cover their costs in the short and medium term.

\subsubsection{What types of students are deterred when fees are introduced?}

Before the analysis moves on to describe how the modified U-curve arises, this section will consider whether there is a pattern to the types of students who, after the introduction of tuition fees, choose to come to Denmark and Sweden or instead choose another country. This is considered both in relation to trends within subject areas and in relation to the student's country of origin.

\section{Developments by subject area}

In Denmark, more international students enrol on programmes in certain subject areas than in others (see Table 3.2). The discipline with the largest proportion of international students (33\% in 2009) is social science, which has increased its share by 17\% between 2005 and 2009. By comparison, the proportion of international students on technical science programmes has fallen by $21 \%$, while in the natural sciences it is up $5 \%$.

\footnotetext{
65 Universities Denmark, Statistics includes enrolled non-EU/EEA students, while figures from the Swedish National Agency for Higher Education and Statistics Sweden (SCB) are for newly registered students. ${ }^{66} \mathrm{~L} 114$, draft amendment to the law on universities (the Universities Act).

67 The Ministry of Finance's budget guidelines.
} 
Table 9: Proportion of international students* on a whole study programme in Denmark, by subject area

\begin{tabular}{lccr}
\hline Subject area & $\mathbf{2 0 0 5}$ & $\mathbf{2 0 0 9}$ & \% change \\
\hline Humanities & $14 \%$ & $15 \%$ & $+9 \%$ \\
Natural science & $18 \%$ & $19 \%$ & $+5 \%$ \\
Social science & $28 \%$ & $33 \%$ & $+17 \%$ \\
Health science & $15 \%$ & $13 \%$ & $-12 \%$ \\
Technical science & $25 \%$ & $20 \%$ & $-21 \%$ \\
\hline
\end{tabular}

Source: The Danish Ministry of Education's Mobility Statistics

*The data does not differentiate between EU/EEA and non-EU/EEA students by subject area, so the table covers all international students on a full programme in Denmark, i.e. those defined as foreign nationals who have lived a maximum of one year in Denmark at the time the programme starts. The data only covers international students who enrolled on ordinary programmes, not students who participate in specially arranged private- or public-sector programmes, such as foundation courses and continuing education courses (e.g. MBAs).

As the figures in Table 3.2 cover all international students, it is not possible to isolate the effect of student fees and thereby extrapolate the direct impact that student fees have had on the subject areas in which non-EU/EEA students enrol. More detailed figures from Universities Denmark, Statistics show that, at $52 \%$ in 2009 , social science programmes are the most popular among fee-paying non-EU/EEA students at universities. By comparison, 30\% of fee-paying non-EU/EEA students were enrolled on engineering and science programmes. ${ }^{68}$ Although, all things being equal, fee-paying non-EU/EEA students constitute a small proportion of the total number of international students, it can be concluded that, overall, social science programmes are the most popular among international students.

Qualitative interviews with Danish universities underpin this. Several interviewees point out two aspects in particular which, taken together, have an effect on the disciplines that appear to be the most attractive to non-EU/EEA students considering whether to pay to study in Denmark. First, the price. The universities do not have the power to set their own prices for programmes, and therefore in practice the prices of individual courses reflect the taximeter rate. As such, the social sciences and humanities (typical taximeter rate DKK 46,200) are the cheapest, while the technical, natural and health sciences are generally more expensive (typical taximeter rate DKK 98,100). ${ }^{69}$ The second is international competition. The Danish universities have to compete in a global market to at- 
tract international students. Non-EU/EEA students may opt to pay to study anywhere in the world - including at elite British and American universities. Stakeholders in Denmark believe that the relatively low price of some Danish programmes, combined with the quality of those programmes and the international rankings, affects the paying student's choice of college or university:

"The fact that prices are at taximeter level means that it costs the same to study engineering in Denmark as at the best American universities and considerably more than in other European countries, while the social science courses are relatively cheap in Denmark compared to other European countries." (Representative, Denmark)

Among the social science programmes, the business-related ones ${ }^{70}$ in particular are relatively cheaper in Denmark than in other European countries. When a student is considering where to study, a number of factors affect the choice of programme. Several interviewees highlight as critical factors the pricing of the programme, the subject area and the university's place in international rankings. For Danish universities, this means - partly because the taximeter sets the price - that it is more difficult to compete at international level in some subject areas than in others.

The initial experience after the introduction of student fees in Sweden is that the natural sciences are the worst affected - a fall of $88 \%$ among paying non-EU/EEA students in autumn semester 2011 compared with the same semester in 2010. By comparison, the fall in the social sciences in the same period was $77 \% .{ }^{71}$

Several Swedish universities are concerned about the impact on the natural sciences, as it is difficult to attract Swedish students in this area. Moreover, these disciplines are linked to strong research environments in which Sweden is at the forefront, and research may potentially be weakened if there is not a certain level of intake of new students. However, international students have helped to maintain student numbers and make the classes financially viable - and, to date, it does not appear to have been necessary to close classes or programmes at Swedish universities or colleges.

\section{Trends in relation to country of origin}

There is a clear trend in the geographical distribution of non-EU/EEA students. In both Denmark and Sweden, the majority are from Asia, followed by students from Africa, North America and European countries outside the EU/EEA. These groups are proportionally of roughly equal

\footnotetext{
70 E.g. programmes at Copenhagen Business School.

${ }^{71}$ Swedish National Agency for Higher Education 05/22/2012: "Statistisk Analys - Färre studenter från Asien efter avgiftsreformen" (Statistical Analysis - Fewer students from Asia after the fees reform).
} 
size in Denmark and Sweden, while South American students make up the smallest proportion in both countries. The situation in Denmark and Sweden also reflects global trends, in which Asian students are the largest group of international students (52\% of the total number of international students in 2009). ${ }^{72}$

A closer look at trends for non-EU/EEA students in the wake of the introduction of tuition fees shows that the biggest fall in both Denmark and Sweden is among students from Asia. In Denmark, the trends have been different for different groups of non-EU/EEA students. For example, the number of African and North American students has increased, while the number from Asia, South America and non-EU/EEA European countries has fallen. In Sweden, there has been a general decline among all groups of students, the biggest decline in students from Asia, Africa and non-EU/EEA Europe, the smallest in students from South America and North America.

In Denmark, there were 961 students from Asia in 2009/10, representing $70 \%$ of all non-EU/EEA students. Among the Asian students, the largest group by far were from China (563), with Nepalese students, the majority on business-academy programmes, the next biggest (140). While the number of Nepalese students has increased over the period, from 16 to 140 , the number of Chinese and Indian students has decreased.

Africa is the continent with the second-highest number of students, mainly from Cameroon (45) and Ethiopia (41). For the other continents, the numbers are significantly smaller.

The trend from 2006 to 2010 clearly shows that, following the introduction of tuition fees, the largest fall is among Asian students (10\%), and then European students from outside the EU/EEA (7\%) and South America (6\%). By contrast, the numbers from North America (31\%) and Africa (19\%) both rose during the same period.

Table 10: Non-EU/EEA students in Denmark by continent of origin

\begin{tabular}{lrrrrrr}
\hline Continent & $\mathbf{2 0 0 5 / 0 6}$ & $\mathbf{2 0 0 6 / 0 7}$ & $\mathbf{2 0 0 7 / 0 8}$ & $\mathbf{2 0 0 8 / 0 9}$ & $\mathbf{2 0 0 9 / 1 0}$ & \% change \\
\hline Africa & 155 & 114 & 88 & 135 & 184 & $+19 \%$ \\
Asia & 1073 & 703 & 757 & 1113 & 961 & $-10 \%$ \\
Europe outside the EU/EEA & 112 & 51 & 85 & 95 & 104 & $-\mathbf{7 \%}$ \\
North America & 55 & 40 & 59 & 53 & 72 & $+31 \%$ \\
South America & 54 & 23 & 24 & 36 & 51 & $-6 \%$ \\
\hline
\end{tabular}

Source: The Ministry of Education, Mobility Statistics.

In Sweden, the first intake of non-EU/EEA students after the introduction of tuition fees shows a large general drop in numbers from all parts of the world. This is not surprising, as the intake of non-EU/EEA students has

72 OECD (2011): Education at a Glance, p.321. 
not yet stabilised, as it has in Denmark. The biggest drop in the number of non-EU/EEA students is among those from Asia (84\%). Of these, the biggest decline is among students from Pakistan, Nepal and Bangladesh.

Although the numbers have still more or less halved, the smalllest declines are for students from South America (49\%) and North America (57\%).

Table 11: Non-EU/EEA students in Sweden by continent of origin

\begin{tabular}{|c|c|c|c|}
\hline Continent & 2010 (autumn) & 2011 (autumn) & $\%$ change \\
\hline Africa & 679 & 147 & $-78 \%$ \\
\hline Asia & 5455 & 853 & $-84 \%$ \\
\hline Europe outside the EU/EEA & 777 & 189 & $-76 \%$ \\
\hline North America & 498 & 212 & $-57 \%$ \\
\hline South America & 121 & 62 & $-49 \%$ \\
\hline
\end{tabular}

Source: Swedish National Agency for Higher Education and Statistics Sweden (SCB).

Overall, there are a number of interesting trends. Despite the introduction of fees, it is interesting that the number of African students in Denmark rose by $19 \%$ in the period from 2006 to 2010 . This may be due to an upward adjustment of the DANIDA scholarships that are awarded to many African students. The overall fall in the number of Asian students in Denmark and Sweden cannot be attributed to students from a specific country. In Denmark, the fall in Chinese and Indian students accounted for the aggregate decline from Asia, while in Sweden it has been caused by students from Pakistan, Nepal and Bangladesh.

\subsubsection{Why does the number of students fall when fees are introduced?}

As shown in Figure 1, the introduction of tuition fees led to a fall in the number of non-EU/EEA students in Sweden and Denmark.

The study reveals three main reasons for a significant fall:

- Fees place entirely different demands on the students' financial resources

- The major change from no payment to full cost (shock effect)

- Nordic programmes that charge tuition fees are in competition with other countries.

\section{New demands on students' financial resources}

Experience in the UK shows that the introduction of a small fee, one that is symbolic in comparison with real costs, does not have a noticeable effect on student numbers. Annual increases in fees from £320 in 1975 to $£ 1,230$ in 1979 had no adverse effect on the number of international students, which increased significantly during that period. However, a change to significantly larger amounts (minimum prices in 1980 were $£ 2,000, £ 3,000$ and $£ 5,000$, depending on the nature of the programme) 
resulted in a reduction. In a way, the UK experience underpins the fact that a sharp price increase to cover costs will have a noticeable effect on the number of students. The Icelandic experience is the same, i.e. the introduction of a small annual registration fee has had no effect on intake. Taking into account a comparative European perspective, it is not very surprising that the number of students falls considerably when significant fees are introduced.

\section{Shock effect}

The shock effect occurs because the introduction of fees turns what has previously been a free education into one that the student has to pay for in full. When, as was the case in Denmark and Sweden, a programme that was free one semester suddenly costs $€ 6,000-€ 15,000$ the next, there are consequences - even though, in most other countries around the world, it is normal for students to pay a large sum for their studies. It was widely known that it was free to study in Denmark and Sweden, and the introduction of fees therefore caused an immediate shock effect.

\section{Competition in an open market}

Nordic countries that suddenly introduce tuition fees have to compete with institutions throughout the world. Other countries have certain advantages:

- Language - English-speaking countries are attractive due to the number of prospective students who master the language

- Cost of living - it is cheaper to live in many other countries

- Fashion - some countries are popular, e.g. Anglo Saxon countries are considered attractive

- Position in official education rankings

- Job opportunities - those seeking an international career after graduation find it easier to get a job in a country where the working language is English.

Culture, history and weather also play a role. Students from the Commonwealth countries enjoy advantages in the UK. A country's reputation - good or bad - for openness and its integration policies play a part. And perceptions of weather should not be underestimated.

The Nordic countries fare better in relation to some of these parameters than others. As far as language is concerned, they are seen as attractive because the level of English on the study programmes is high. However, the national languages do constitute a barrier in relation to graduate job opportunities, as many workplaces in the Region make spoken and written mastery of the local language a prerequisite.

For some groups of students, the Scandinavian countries may seem to be "in" and fashionable. On the other hand, the cost of living in the Nordic countries is relatively high compared to other Western countries, 
and Nordic universities are not highly placed on the official rankings. These factors may make the Nordic countries seem like a less attractive place to study.

\subsubsection{Why are numbers rising again?}

Several reasons explain the resurgence in the number of students from the EU/EEA, as seen on the modified U-curve.

The study identifies:

- consolidation in the market

- scholarships

- marketing - including exchange agreements as a tool

- support for students on arrival and through induction

- the content of the study programmes.

Each of these factors is rooted in a number of social and institutional levels. One such level is the global education market, in which multiple political processes and levels interact and play a role in the consolidation of the marketplace. The Nordic scholarship schemes vary but they are mainly state-controlled. Finally, the universities are important players in the education market, and make use of, e.g. marketing initiatives to attract students.

\section{Consolidation in the market}

In most countries, HE study programmes are, first and foremost, a commodity with a price. From an international perspective, Nordic HE has been - and some cases, still is - unusual because it has been free for nonEU/EEA students. The u-curve increase reflects the fact that shock effects wear off. In time, the international market consolidates, and international students return to the Nordic countries, either as paying students or as recipients of scholarships.

\section{Scholarships}

One crucial aspect is the scholarship schemes, which mean that many non-EU/EEA students do not have to pay.

The table below shows how the amount spent on scholarships has increased in Denmark:

\begin{tabular}{lc}
\hline Year & mDKK \\
\hline 2006 & 2.9 \\
2007 & 9.6 \\
2008 & 22.3 \\
2009 & 28.7 \\
\hline
\end{tabular}


In Denmark, both the funding for and the number of scholarships increased significantly in the first four years of fees. This had a major effect on student numbers, as scholarships compensated for impact of the fees.

\section{Marketing}

The introduction of tuition fees for non-EU/EEA students requires Danish and Swedish HE institutions to increasingly operate in a global education market, which requires new and different approaches to marketing programmes. A factor contributing to the u-curve, and the number of students rising again, is that efforts are being made both at national and university level to market programmes.

Swedish stakeholders point out that the institutions that cope best with the introduction of fees - i.e. those with the smallest fall in the number of students from non-EU/EEA countries - are those that already have good international relations and partnerships:

\footnotetext{
"The many students who have arrived in the last decade, e.g. from Pakistan and Bangladesh, are not the result of a conscious policy. It is more of a coincidence, a reflection of the fact that we did not have tuition fees. As a result, some universities have not worked well on recruitment and marketing abroad, and those are the ones facing problems. They do not have a strategy to fall back on. It also takes a long time to build up relationships and a reputation abroad, so it may be some time before they catch up." (Representative, Swedish university)
}

During qualitative interviews it has also emerged that specifically working to recruit international students is new for some Danish and Swedish universities. Since education in the Nordic countries has long been free for non-EU/EEA students, and therefore attractive to a very broad range of students, the introduction of fees meant that the universities have had to rethink their marketing strategies. As previously mentioned, there is a group of students who think that free education cannot be of sufficiently high quality. The introduction of fees has therefore opened up new opportunities to target this group.

In the UK, after the fall in the number of international students, the universities clearly considered marketing to be an important strategic tool for attracting more international students. A 1985 survey of 33 British universities showed that $90 \%$ were involved in marketing activities abroad, and 70\% had beefed up and improved their marketing and recruitment strategies since $1980 .{ }^{73}$

73 Woodhall, Maureen (1989): "Marketing British Higher Education Overseas: The Response to the Introduction of Full-Cost Fees', Higher Education Quarterly, Vol. 43, issue 2, pp. 142-159. 


\section{Major differences in marketing between universities}

The University of Southern Denmark has put a great deal of effort into marketing its programmes, with a particular focus on social media such as Facebook, Twitter and LinkedIn. In terms of the number of friends/followers, the University of Southern Denmark is one of the ten best-known universities in the world. ${ }^{74}$ Roskilde University has concentrated on marketing natural science, as it has found it difficult to attract Danish students to these programmes:

"So the introduction of fees is a great advantage because paying students fill up the places." (Representative, Roskilde University)

Other universities do not think that the introduction of tuition fees has had a significant effect on their marketing strategy. For example, one Danish university points out that it had already drawn up a comprehensive strategy for attracting international students. The same is true of Copenhagen Business School, which points out that its programmes were already popular with this target group. Other universities say that they have not changed their marketing, and have not put greater emphasis on recruitment.

In both Sweden and Denmark, the importance of geographical location is abundantly clear. The universities of Copenhagen and Stockholm are aware that being located in national capitals gives them an advantage when it comes to recruitment and marketing.

More than half of the respondents to a questionnaire survey by the Swedish National Agency for Higher Education said that they had intensified recruitment drives in relation to international students.

Those who have changed their approach have often made use of agents abroad, and placed greater emphasis on the Internet and social media. Recruitment by alumni is also widespread, as is hiring staff to work specifically on the recruitment of international students.

\section{Example:}

The University of Gävle, which had already built up a good relationship with China, continues to work on its marketing and has made it an even higher priority.

Even although it gave its partner universities plenty of warning, the number of Chinese students still fell significantly when fees were introduced. Gävle is considering expanding its promotional activities into Korea, for example, where there are not many domestic universities.

The greater emphasis on marketing has demonstrated that they are new on the market, whereas the American and English universities, for example, are already well known.

"We can feel that we are the new guys, and that we need to go out and make our mark," says the international coordinator at the University of Gävle.

${ }^{74}$ According to the Rector of the University. 
On behalf of its members, SUHF has noted that there is no overall vision and commitment from the Swedish state in relation to marketing.

\footnotetext{
"The Swedish Institute should be in charge of central marketing of Swedish higher education, but funding is inadequate. At national policy level, they underestimate what it takes to implement the sort of marketing that is needed." (Representative, Swedish university)
}

In order to boost recruitment, 32 universities and colleges have joined together in the project "Study Destination Sweden." This was initially led by the Swedish Institute but there is interest in continuing to work together after the end of the project period. The aim is to create a platform for questions to be raised and for co-operation on international recruitment and marketing.

\section{Joint Nordic marketing}

Joint Nordic marketing of study programmes used to be quite widespread. Several stakeholders point out the effects of Sweden and Denmark introducing fees:

\footnotetext{
"It is clear that competition is different now than it was when tuition fees were introduced in Denmark in 2006. After the Swedes introduced them in 2011, we find that it has caused ructions in Nordic co-operation. The Swedes have opted out of joint Nordic marketing, so at fairs we have a Nordic stall, while they have their own." (Representative, Danish university)
}

Just as the overall marketing of a country as an educational nation can give HE providers a basis on which to build, strengthening the Nordic Region as an education region would give the institutions a better starting point from which to market themselves globally. It would help to create a platform both for the countries and for the universities. It is therefore unfortunate, at a time when there is a greater need than ever before for marketing and recruitment partnerships, that there is a trend towards less co-operation.

\section{Exchange agreements as a marketing tool}

The Swedish National Agency for Higher Education's report "Avgiftreformen - lärosätanes förste erfarenheter" (The fees reform - first impressions) shows that 15 of the 35 universities and colleges in Sweden who were surveyed say that they now work differently as a result of the introduction of tuition fees.

When used in conjunction with marketing efforts, exchange agreements can help to reverse the decline in numbers and encourage the ucurve to swing upwards. If, due to an exchange programme with a university in Sweden, a region in China sees the potential and recognises the academic quality available in the country, then this may pave the way for future paying students. 
Exchange agreements, and the imbalances within them in both Sweden and Denmark, have been discussed in connection with Swedish legislation as a way of avoiding charging tuition fees. Exchange agreements have thus been seen as a barrier to realising the intention behind the reforms. In practice, conversely, exchange agreements are also used as gateways to marketing initiatives and to establishing relationships with countries and regions where there is potential to attract paying students.

\section{Support and initial reception}

In relation to marketing, it is also crucial that universities improve the reception and induction of new students, and in general help them to establish themselves as international students, e.g. by addressing their social conditions, providing mentoring schemes and welcome events, helping them with accommodation, the local language, etc.

Many universities in Sweden have chosen to do more work on supporting induction and integration. In a recent survey conducted by the Swedish National Agency for Higher Education, ${ }^{75} 22$ out of 34 universities and colleges said that they have improved support for students, particularly in relation to housing, reception and introductory courses in Swedish, which are popular at the universities that have chosen to make student support a higher priority and part of their work on recruitment, marketing and retention.

The quality of the reception they will receive is part of the overall package students look at when choosing a study programme. The Danish International Student Barometer 2008 showed that Denmark scored low on reception and integration. Partly in light of this study, the Globalisation Agreement of 2009 granted additional funding for the development of reception packs aimed at improving induction for international students. Several Danish educational institutions have prioritised improving this part of their work. Initiatives include:

- Free Danish classes from 2010 (change to the Integration Act).

- The International Citizen Service (www.icitizen.dk).

- Workindenmark.dk prioritising international students.

- The project "Interresource" (Region Mid-Jutland).

- Copenhagen Talent Bridge (Capital Region).

The Danish International Student Barometer 2011 documented a positive trend in this area. It identified the local and specific effects of good reception packs for students considering the institution concerned.

75 Swedish National Agency for Higher Education (201112 R): "The fees reform - first impressions." 


\section{The content of the study programmes}

In order to make programmes more attractive to international students, the universities also need to put more thought into targeting their study programmes, e.g. by offering a wider range of subjects in English and incorporating a global perspective. This is an important way of inducing an upswing on the u-curve, i.e. increasing the number of students from countries outside the EU/EEA.

For example, Danish stakeholders point out that $25 \%$ of subjects at the University of Southern Denmark are now in English, and that this percentage has risen. The University also prioritises globalising the subjects it offers so that international students are able to benefit from them as well. As part of its international marketing efforts, the University of Copenhagen introduced the Copenhagen Masters of Excellence (COME) programme in 2009, the aim of which is to establish 15-20 two-year English-language Master's programmes, partly to make the university more attractive to international students.

The other Danish universities have not taken any additional action to introduce more international programmes after the introduction of tuition fees. These universities point out that it is already a part of their overall mission to be internationally oriented and attractive to international students.

\subsection{Consequences for Nordic co-operation}

As this study has shown, practices regarding tuition fees vary throughout the Region. This section will consider whether the different rules for tuition fees affect Nordic co-operation on higher education.

The short answer is that the different rules do not represent insurmountable obstacles to co-operation in the Region, although difficulties have been encountered in relation to specific initiatives, e.g. the Council of Ministers' NMP. This will be discussed below.

\subsubsection{General restrictions to cross-border freedom of movement as a result of different rules on tuition fees}

In their responses to the study, neither government agencies, interest organisations nor educational institutions indicate that the different rules on tuition fees constitute significant challenges to Nordic co-operation.

In relation to mobility between the countries, understood as the students' opportunities to take elements of their study programme in different Nordic countries, the stakeholders do not think that there are any significant problems for students from either EU/EEA or non-EU/EEA countries. It is not surprising that students from Nordic countries or other EU/EEA countries are not affected, since the rules do not affect their conditions. 
This view held by the stakeholders may be due to two factors. Firstly, few non-EU/EEA students avail themselves of the opportunity to devise a study programme based on elements in different countries. Secondly, it is unlikely that the stakeholders would be aware of any challenges such students did encounter - students put the programme together themselves, and therefore any challenges encountered in this area would not involve the universities and official agencies.

Several stakeholders suggest that the countries could do more in terms of marketing: specifically, they could market the Nordic Region as an educational region. Some also point out that student fees increase competition between the countries, and can therefore act as a barrier to working together on Nordic marketing in higher education.

With this in mind, the study concludes that if students from nonEU/EEA countries do face challenges in this context, then it is only to a limited extent. This conclusion suggests a need to find out how large the group is, and what challenges it faces as a result of different rules on tuition fees.

\subsubsection{Experiences of NMP}

When the NMP evaluation was conducted in 2010, Denmark was the only Nordic country that had introduced tuition fees for all non-EU/EEA students (in 2006), while Finland had taken a decision on a pilot scheme with tuition fees for the period 2010-2014 for non-EU/EEA students. In Sweden, the decision had been taken to introduce full-scale tuition fees (as in Denmark) from the 2011 autumn semester.

Qualitative interviews conducted with project co-ordinators as part of the evaluation showed that the different rules about tuition fees had given rise to two challenges in relation to the planning and implementation of the NMP. Firstly, participating institutions have unequal opportunities when it comes to attracting non-EU/EEA students. Secondly, it is not possible to give students clear advice on the financial aspects of their programmes, because the costs of an NMP depend on the subject and mobility options chosen by the individual student. However, the first challenge is only relevant for some types of programmes, and is therefore local and limited in extent. The established NMP programmes are very different in intake and structure, and so there are major differences in the extent to which the different rules for tuition fees constitute barriers to participation. ${ }^{76}$

Interviews with NMP co-ordinators conducted in 2012 present a similar picture. Only a few of them suggest that the different rules on tuition

76 Oxford Research (2010): “Evaluation of the Nordic Master Programme." 
fees affect co-operation. There are no insurmountable barriers, but in certain areas the different rules for individual programmes make cooperation on NMP difficult.

The three examples highlighted below show how the different rules can hinder co-operation in some types of programmes.

Example 1: The ambiguities in Nordic co-operation were brought to light by a programme at a Swedish institution. The programme agenda for 2010 was to include discussions on whether the intake should be relocated to an institution in a country that does not charge tuition fees, since Sweden was just about to introduce them at the time (from autumn semester 2011). The discussion revolved around the fact that it would be easier for the NMP to attract non-EU/EEA students if they did not have to pay. In addition, it was agreed within the programme that students should only have to pay fees to a Danish institution if they took more than one semester there. The reason for this is that they are considered exchange students if they only spend one semester in Denmark.

In 2012, these students are still enrolled in Sweden. The partners behind the programme tried to work out what significance this would have for the intake. A reduction from 30 to seven students from 2010 to 2011 means that the consortium has now decided that the intake will be moved to Norway from 2013. The 2012 intake includes 14 non-EU/EEA students.

Example 2: An NMP programme involving five universities in four countries operates with a decentralised intake, i.e. the students decide at which institution they will enrol. The programme works with a $1+1$ model - the students spend a year at the institution where they are enrolled, and a year at one of the other universities. The challenge is that many of the students now apply to Norwegian institutions because of the tuition fees elsewhere. This means that the Norwegian institutions face higher administrative costs, and the intake is not distributed evenly. The programme is working on a solution to recommend to the Council of Ministers. The programme co-ordinator points out that Erasmus Mundus offers a joint programme for the same price, despite different rules about tuition fees.

Another programme with decentralised intake, and so similar fears that all of its students will enrol in Norway, has sought to reach an agreement about how to deal with the potential challenge. The agreement stipulates that the intake must be balanced, i.e. agreed and coordinated between the co-operating parties. A third programme, which does not yet have any experience with an actual intake, offers students the chance to choose between two study lines - one in Denmark and the other in Norway. Here too, it is feared that many students will not choose Denmark because of tuition fees, and that the Danish part of the programme will suffer as a result.

It is important to mention that only a limited number of students are involved. Firstly, because the number of NMP students is limited in general. Secondly, because this issue only affects NMP students from non- 
EU/EEA countries. To date, approx. 30\% of NMP students have been from non-EU/EEA countries. However, no data has been collated about the proportion of them who have paid tuition fees.

Example 3: Another NMP programme is experiencing challenges in putting together a programme that involves both countries that require fees and countries in which it is illegal to enrol students and later charge them for part of their programme. An attempt to solve this problem is being made by incorporating a stipulation into the co-operation agreements that students enrolled in Norway must not be charged fees in the other countries involved in the programme.

\section{Barriers to student mobility in NMP}

The Nordic Council of Ministers commissioned Oxford Research to conduct a survey of NMP students in 2012. It followed up on the one conducted as part of the 2010 evaluation of the NMP. The latest 2012 NMP survey highlights the mobility dimension in greater detail than the previous survey, e.g. students cited the different rules on tuition fees as a barrier to Nordic mobility.

Figure 2, below, shows the factors that non-EU/EEA NMP students say restrict their mobility. By some margin, the cost of living is the most common challenge, with $82 \%$ saying it was a barrier to their mobility to a high degree or to some degree. Next comes lack of financial resources (66\% see this as a barrier to a high degree or to some degree) and finding a place to live $(40 \%$ see it as a barrier either to a high degree or to some degree).

Figure 2: Barriers to non-EU/EEA students' mobility in NMP (n= 91)

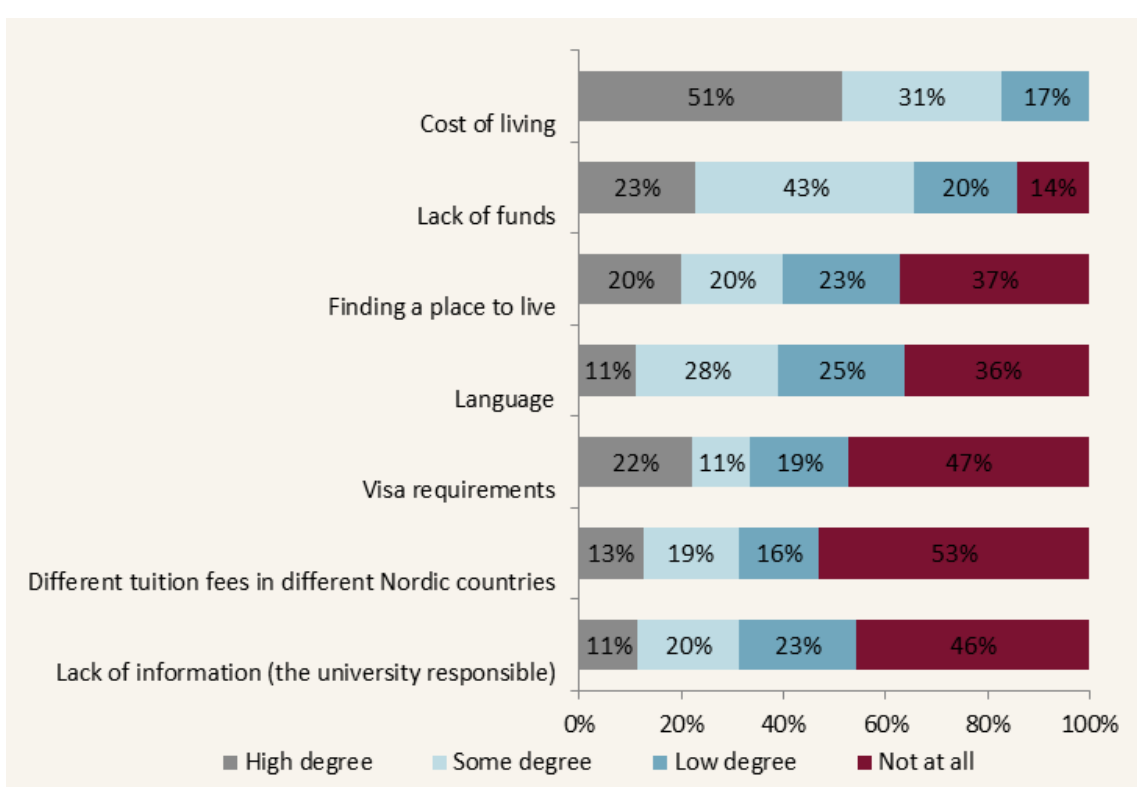


The different rules for tuition fees in the Nordic countries are not the primary barrier to the mobility of non-EU/EEA students - only approx. one third (32\%) cited this as a factor to a high degree or some degree. At the same time, 53\% of non-EU/EEA students do not see it as a barrier at all. It should be noted that it has not been possible to identify the proportion of NMP students who have paid tuition fees in the Nordic countries.

Of the 12 students who responded that the different policies on tuition fees constitute an obstacle to a high degree or to some degree, half are students on the same programme (one of eight programmes in total). This emphasises that the challenge is local and limited to specific types of NMP programmes. Several co-ordinators point out that there is a discrepancy between the number of non-EU/EEA students who apply for an NMP and the number enrolled. One hypothesis is that tuition fees in some countries discourage students from studying in the Region. In the context of this study, it has not been possible to identify how many students did not enrol on an NMP due to tuition fees.

To conclude, certain programmes, because of the specific type of programme, the admission procedure and the countries involved, face certain challenges, and attempts are being made to resolve them, e.g. via cooperation agreements. However, these challenges are not crucial to cooperation in general, and only affect a small group of students. In the longer term, it is possible to envisage that different rules may cause difficulties that will discourage Nordic HE institutions from entering into certain types of collaborative ventures. Conversely, however, other forms of collaboration are not affected by the different rules on tuition fees. 



\section{Perspectives}

This final chapter looks at perspectives for the future by presenting the current economic context as well as the most pressing arguments for and against fees in the Nordic Region.

\subsection{Economic context}

Before outlining the perspectives for tuition fees in the Nordic Region, it is worth considering the European economic context for higher education in order to gain a sense of the resources devoted to HE in the Nordic countries compared to peer countries.

Table 12 shows the Nordic state spending on HE as a share of total GDP in 2008.

Table 12: Spending on higher education as \% of GDP

\begin{tabular}{ll}
\hline Country & \% of GDP \\
\hline Norway & $2.9 \%$ \\
Denmark & $2.2 \%$ \\
Finland & $1.9 \%$ \\
Sweden & $1.8 \%$ \\
Iceland & $1.5 \%$ \\
The Netherlands & $1.5 \%$ \\
Great Britain & $0.8 \%$ \\
OECD (average) & $1.3 \%$ \\
The EU21 (average) & $1.3 \%$ \\
\hline
\end{tabular}

OECD (2011): Education at a Glance, p. 2011.

The Nordic countries come out top of both the EU and OECD spending lists. This suggests that the costs associated with running Nordic HE are relatively heavy. All of the Nordic countries feature in the OECD top five for public spending as a percentage of GDP. They are also the OECD countries that fund the largest proportion of their HE systems from the public purse. In 2007, over 95\% of HE funding in Finland, Norway and Denmark came from the state, compared to the OECD average of 79.4\%.77

The economic context is, therefore, that the Nordic countries spend large amounts of public money on HE. The introduction of tuition fees may therefore be based, among other things, in an economic rationale. In

77 CAI, Yuzhuo \& Jussi Kvistö (2011): “Tuition Fees for International Students in Finland: Where to Go From Here?', Journal of Studies in International Education, pp. 1-24 
this way, awareness of, and trends in, public spending on HE can be a deliberate choice that reflects the way in which the individual countries implement the Nordic welfare model in the HE sector.

\section{The UK experience}

In the UK, the economic rationale has been dominant for the last 30 years. In 1980, "full-cost fees" were introduced for non-EU/EEA students, meaning that they would effectively fund part of the HE sector. Immediately after the introduction of full-cost fees, the number of applicants to universities fell sharply but increased rapidly and significantly again in later years. This was due to marketing efforts that targeted nonEU/EEA students, as well as favourable educational conditions for international students. ${ }^{78}$ Since 1983, and despite increasing tuition fees, the proportion of non-EU/EEA students in the UK has continued to increase. ${ }^{79}$ If these students then find work in the UK, studies show that they make a significant positive economic contribution to society. 80

In 1983, the government improved scholarship opportunities for non-EU/EEA students by earmarking $£ 46$ million over three years, primarily for use by existing funds such as the Commonwealth Scholarships. Extensive investments in the Prime Minister's Initiative, which was introduced in 1999 for the first time and revised in 2006, also improved opportunities for scholarships for international students. In addition, the UK universities launched marketing campaigns abroad and streamlined procedures for new arrivals and induction in the universities. These initiatives have all helped raise the number of international students in the UK since 1984, and the numbers are now higher than ever.

It is particularly interesting to note that in England, from autumn 2012 , university tuition fees were increased by up to $300 \%$, to as much as $£ 9,000$ p.a. for home students. Fees were imposed on all British university students in 1998. The rationale behind the introduction was lack of economic resources in the HE sector. The Dearing Report (1997) suggested that a rate of $£ 1,000$ p.a., 81 combined with scholarships and loans, would be an appropriate method of generating revenue. In 2004, the limit on what English universities were allowed to charge British and EU students was increased to up to $£ 3,000$, and then raised again in 2011 , to

\footnotetext{
78 This refers primarily to the existence of high-profile universities (Oxford and Cambridge), connections with former colonies that have favourable co-operation agreements via the Commonwealth, and linguistic advantages for students in and outside the universities.

79 In recent years it has primarily been China, Saudi Arabia and Eastern European countries such as Romania and Bulgaria that have driven growth. HESA Students in Higher Education Institutions 2010/2011, Higher Education Quarterly, 1989.

${ }^{80}$ Vickers, Phil \& Bahram Bekhradina (2007): The Economic Costs and Benefits of International Students, Higher Education Policy Institute (HEPI).

81 There are several subtleties in the report and subsequent legislation, e.g. that tuition fees are conditional on parental income.
} 
the present maximum of up to $£ 9,000$ p.a. Applications for the autumn semester 2012 at English universities show that the number of British applicants has fallen by $9.9 \% .{ }^{82}$ Studies of the applications suggest that it is primarily students from the lower socio-economic groups who are affected. These students choose universities with lower tuition fees, live at home or apply for study programmes with a high "return on investment," i.e. programmes at prestigious universities, or ones that will maximise their future earnings potential. 83

\section{The Dutch experience}

The Netherlands brought in tuition fees for non-EU/EEA students in 1996. Experience suggests that there has been no noticeable long-term effect on the intake of international students. ${ }^{84}$ Indeed, the number of non-EU/EEA HE students increased from 13,900 in 2005 to 19,450 in $2011 .{ }^{85}$ Fees for non-EU/EEA students are in the range $€ 5,000-€ 9,000$ p.a. at Bachelor level and €7,500-€12,750 at Master's and PHD level.

Most of the non-EU/EEA students at Dutch universities are from countries such as China $(5,700)$, the USA $(1,650)$, Turkey $(1,350)$, Indonesia $(1,200)$, India (800) and Surinam (550). ${ }^{86}$ The relatively high number of students from Turkey, Indonesia and Surinam can be attributed to the special social and cultural links the Netherlands has with these countries. ${ }^{87}$ Research shows that the reasons international students choose the Netherlands include high academic standards and the cosmopolitan atmosphere in the country. 88

Dutch universities have been heavily involved in the recruitment of international students for many years. With the introduction of tuition fees for non-EU/EEA students, the Ministry of Education actively encouraged universities to attract more of them. At national political level, an internationalisation strategy, focusing on the recruitment of international students, has been drawn up and political awareness of the issue has increased in recent years. This is because international students are seen as a strategic resource for the country - especially in the natural science disciplines, where there is a lack of Dutch students. ${ }^{89}$ This strategic ap-

\footnotetext{
82 http://www.bbc.co.uk/news/education-16787948

83http://www.youthsight.com/media-centre/wp-content/uploads/2012/03/OpinionPanel-2012-applicantssurvey-Press-release-05080212.pdf

84 Woodfield, Steve (2009): Trends in International Student Mobility: A comparison of National and Institutional Policy Responses in Denmark, Germany, Sweden and the Netherlands.

85 Nuffic (2012): Mapping Mobility 2012: International Mobility in Dutch Higher Education

86 Nuffic (2012): Mapping Mobility 2012: International Mobility in Dutch Higher Education

87 Woodfield, Steve (2009): Trends in International Student Mobility: A comparison of National and Institu-

tional Policy Responses in Denmark, Germany, Sweden and the Netherlands.

88 Nuffic (2008): New brand puts Dutch higher education on the map.

${ }^{89}$ Woodfield, Steve (2009): Trends in International Student Mobility: A comparison of National and Institu-

tional Policy Responses in Denmark, Germany, Sweden and the Netherlands.
} 
proach also resulted in Nuffic ${ }^{90}$ opening the first Dutch NESO ${ }^{91}$ abroad in 2001. The Netherlands now has seven offices in six countries, China, Indonesia (two offices), Mexico, South Korea, Taiwan and Vietnam.

The Netherlands has a well-developed scholarship system for international students. Scholarships are awarded at both state level and university level. In 2006, one quarter of the international students in the Netherlands received a scholarship, either through one of the big international scholarship programmes, via a Dutch programme, or from their home country. Even though only half of the international students in the country are European, Europeans received $83 \%$ of all scholarships, followed by Asians (12\%) and Africans (3\%). In 2006, the government also decided to invest €4.8 million in scholarships for international students. ${ }^{92}$

Overall, the economic context helps to highlight two things. The Nordic countries devote considerable resources to HE - more than the countries with which they usually compare themselves. The economic context also shows that other European countries - primarily based on an economic rationale - have introduced tuition fees. In the UK, they were first introduced for non-EU/EEA students and later also for home students.

\subsection{Arguments for and against tuition fees}

Both during interviews for this study, and in the literature in general, arguments have been posed for and against the introduction of tuition fees. The focus below is on arguments relevant to the context of the study, and therefore to the ongoing debate about tuition fees in the Nordic Region.

\section{Arguments for tuition fees}

One of the main arguments in favour of tuition fees is socio-economic. In a Nordic context, one part of this is reluctance to fund international students since they will return to their home country and work there after graduation. The argument is partly rooted in studies that show that the majority of international students leave the Nordic countries again after they graduate. ${ }^{93}$ The second part of this argument is that international students leaving the country again after a free education potentially

\footnotetext{
${ }^{90}$ Nuffic - Netherlands organisation for international cooperation in higher education.

91 Netherlands Education Support Office.

92 Woodfield, Steve (2009): Trends in International Student Mobility: A Comparison of National and Institutional Policy Responses in Denmark, Germany, Sweden and the Netherlands.

${ }^{93}$ See Finland, for example: "Studies show that approximately $60 \%$ of international students would be willing to stay in Finland to work at least for some period of time if they found a job, but only about one tenth succeed in doing so "(http://ayy.fi/blogi/2011/06/).
} 
results in a regressive ${ }^{94}$ distribution of the benefits of the welfare model. The benefit that society derives from international students is marginal compared to home students, who stay, contribute to society and pay higher taxes after graduating. Put at its bluntest, this means that, because Nordic HE is mainly state-funded, the lowest-paid (who are underrepresented in HE) pay, through their taxes, a share of the international students' free education. ${ }^{95}$ The introduction of fees is therefore seen as a way to (re)introduce a more equitable distribution of wealth. One of the interviewees in the study posed the rhetorical question, why should you have to pay to send a child to nursery in the Nordic countries, but not to go to university? The introduction of tuition fees for non-EU/EEA students in some Nordic countries can therefore be read as a signal that those countries are ready to reconsider their wealthdistribution policies.

A second economic argument in favour of tuition fees is about establishing a revenue stream for the state. Countries regularly face economic challenges when demographic trends increase pressure on state budgets. The introduction of tuition fees for non-EU/EAA students is one way of reducing the HE sector's share of total public spending. According to this argument, tuition fees serve to relieve pressure on, and generate revenue for, the state and HE institutions.

A third argument in favour of fees focuses on the current welfarestate model. This argument contends that free education has outlived its usefulness in a globalised world, i.e. if it is difficult for home students to gain access to HE because of growing pressure from international students, then the model has run aground.

Other arguments in favour of fees are primarily about the perception of HE among students who come to the Nordic countries. One such argument, echoed throughout the Region, is that students increasingly see a link between payment and quality, i.e. if you pay for a programme then the quality is high, and vice versa. Based on this way of thinking, tuition fees in the Region help to signal the fact that Nordic HE provides high quality at a fair price. However, this depends on ensuring a sensible balance between quality and price, especially since competition is so fierce in the HE sector. A second argument in favour of tuition fees, which relates to students, is that they make it easier to attract the "right" international students to the Region - defined as students who wish to train in fields where there is a shortage of skills and specialisation in the Nordic countries - and that incentives for these students to work in the Region after graduation can

\footnotetext{
94 Understood as progressive taxation, see Cai \& Kvistö, p.3.

95 Cai, Yuzhuo \& Jussi Kvistö (2011): Tuition Fees for International Students in Finland: Where to Go From Here?, Journal of Studies in International Education, p.3.
} 
be established. The - purely empirical ${ }^{96}$ - argument is that the introduction of tuition fees means that fewer international students will come to the country but that, partly by means of scholarships, it is possible to create incentives to attract the "right" students. In other words, students who are either the most talented or who have an interest in areas in which there is a demand for skills or labour. Tuition fees are, therefore, a tool with which to attract the right students to the country.

\section{Arguments against tuition fees}

One of the main arguments against fees is that they represent a break with the welfare state established in the Nordic countries over the last 50 years, one of the cornerstones of which is free education for everyone to ensure social mobility and equal opportunities for all, irrespective of financial standing. Proponents of this argument say that resources still need to be earmarked to ensure that all students, both those in the country and those who come to the country, are able to study for free. They see HE graduates as a form of social capital that adds to society and helps companies to develop. ${ }^{97}$

A second key argument against tuition fees concerns the benefits that international students bring to Nordic HE institutions. In an increasingly globalised world, supporters of this argument note that international students add great value to programmes. They add diversity to classes, challenge established practices and add new angles and ideas to teaching. They also add value after graduating, both as labour and as net social contributors if they remain in the country. Even if they move away again, the argument goes that they take with them social and academic networks and relationships built up during their studies. In effect, they serve as "ambassadors" for the host country. The fact is, according to this argument, that international students add both cultural and academic value to the HE sector, and the introduction of tuition fees would dilute this effect.

A third argument is that the introduction of payments for some programmes, or some types of students, will "open the door" to more widespread charges. This "thin end of the wedge" argument is usually put forward by student bodies in countries that are debating the introduction of fees. They fear that once the practice is introduced it will later be extended to home students, as was the case, for example, in the UK.

As a fourth argument against fees, the literature suggests that the Nordic countries would face major challenges, on several fronts, in attracting large numbers of students who have to pay a considerable sum for their

\footnotetext{
${ }_{96}$ Cai, Yuzhuo \& Jussi Kvistö (2011): Tuition Fees for International Students in Finland: Where to Go From Here?, Journal of Studies in International Education, p.8. Brooks, Rachel \& Johanna Waters (2011): Student Mobilities, Migration and the Internationalization of Higher Education, p.2.
} 
education. Studies of what prospective students are looking for when choosing a study programme suggests that they place particular emphasis on the quality of the programme, academic reputation (ranking) and study-related costs (tuition fees, cost of living, learning languages, etc.), as well as opportunities for work after graduation. ${ }^{98}$ Documenting the quality and academic reputation of their programmes can be a particular challenge for the Nordic countries and may lead to students opting to turn elsewhere in the globalised HE market. The cost of living is another problem that may make the Region less attractive, as may the fact that although programmes are taught through the medium of English, a different language is spoken in the country outside of the classroom. ${ }^{99}$

\subsection{Perspectives for the future}

What perspectives does this study identify for tuition fees in the Nordic Region?

Three of the five countries have already either fully or partially introduced tuition fees, and two have deliberately chosen not to. Where fees have been introduced, the rationale has been partly economic, aimed at limiting and redistributing public expenditure on higher education. Mounting economic pressure on this part of the public sector in the three countries has thus been one reason why tuition fees have been introduced.

The study shows that there are significant advantages associated with having international students on HE programmes, in the form of diversity in institutions, as a potential source of labour after graduation and as cultural and academic ambassadors for the Nordic countries. However, the study also shows that the number of international students falls when tuition fees are introduced. In the countries where fees have been introduced, scholarship systems partially offset the impact. Without them, these countries could be forced to alter their practice in some other way.

The study identifies a range of interesting perspectives that are worth discussing in this context. There is a need to strike the right balance between an HE system that optimises public spending and, at the same time, ensures that a significant number of non-EU/EEA students come to the Nordic countries. It is possible to attract non-EU/EEA students to the Region, either for a free education or for one subsidised by scholarships - the empirical evidence shows this. However, the art is in attracting talented students who will either pay their own way or will

\footnotetext{
${ }_{98}$ Cai, Yuzhuo \& Jussi Kvistö (2011): Tuition Fees for International Students in Finland: Where to Go From Here?, Journal of Studies in International Education, p.11. 99 Ibid.
} 
work in the Region after graduation. This makes a difference. The study provides some indications of ways in which this potential could be exploited. In the first instance, the need to document quality can be met by focusing on climbing the international rankings or by focusing on more targeted marketing of potential students. When study programmes cost money, students expect high quality - and institutions need to be able to document the quality of their programmes. Secondly, more attention could be paid to identifying and publicising job opportunities in the Region after graduation. Not enough attention is paid to this at the moment, and it could have a positive impact in terms of attracting students to the Nordic countries. By tracking international graduates' employment in this way, Nordic HE institutions would be able to differentiate themselves in their marketing from programmes elsewhere and obtain useful knowledge about what international students go on to do after graduation. Thirdly, the universities could deliberately set the price of programmes at a level that is attractive to international students in order to make it possible to compete in the global market and generate income for the universities. The trick is to find the level that students consider attractive, but which also covers most of the costs associated with the programme concerned.

It is important to keep in mind that these three elements need to be integrated into an overall strategy to attract fee-paying international students. If documentation is available for the quality of the programmes and for prospective routes to the labour market after graduation, then the study suggests that it will be possible to attract international students who are willing to pay to study in the Nordic Region. The United Kingdom has proven this. Conversely, the study also shows that such documentation is minimal at the moment, and that this represents an obstacle to increasing the number of international students in the Region. One option would, therefore, be to use short-term, strategic pricing to raise the profile of certain types of study programme. However, at the same time, it is important to keep in mind that price alone does not sell. It is when the price is attractive and quality is assured that international students are willing to study in the Nordic countries. ${ }^{100}$

The future for tuition fees is very much a political decision and, at present, there is no consensus between the five Nordic nations about what a welfare state should provide, what the countries are able to afford and what future perspectives they envisage in relation to international students.

100 Copenhagen Business School (CBS) is an example of this. The price is generally considered reasonable relative to other educational institutions in Europe, and CBS also fares reasonably well in international rankings. 


\section{Methodology}

Our methodology followed two parallel tracks - desk research and fieldwork. The main purpose of dividing the analysis up into two methods of data acquisition was to access all of the relevant sources and make sure no stone was left unturned. It was also important that the two tracks interconnected and continuously supplemented and supported each other throughout the process. The field research comprised qualitative interviews with representatives of relevant Nordic bodies; international offices in educational institutions; educational organisations; and NMP co-ordinators. This brought to light experiences with tuition fees and provided insights into a range of issues relating to their introduction. The desk research supplemented the insights from the field research with knowledge and information derived from reports and analyses of the fees issue. Relevant statistical data was also studied to identify trends in the intake of non-EU/EEA students and quantify the impact of tuition fees.

\subsection{Data acquisition}

Data was acquired by the following methods.

Desk research:

- Review and analysis of statistical data.

- Review of literature (reports, memoranda, etc.).

- Review of relevant websites.

Field research:

- Interviews with representatives of relevant public-sector agencies in the Nordic Region.

- Interviews with representatives of Nordic educational institutions/organisations.

- Interviews with NMP co-ordinators.

- Interviews with British educational experts. 


\subsection{Desk research}

\section{Review and analysis of statistical data}

One of the most important tasks has been to examine the statistical data available for the Nordic countries. This is because one of the main objectives of the analysis was to study the impact of the introduction of tuition fees, and statistical data is a key source of information about nonEU/EEA student numbers in the Region. To ensure that we were using the most relevant statistical data, we approached the officials responsible in the respective Nordic countries.

Since differences exist in the way the Nordic countries collate data, the study makes clear what the figures for each country contain and cover. It is, therefore, important to be aware that trends in the intake of non-EU/EEA students are not always directly comparable, but that the figures for the individual countries may indicate the overall trend in non-EU/EEA student numbers in each country.

\section{Literature review}

A systematic review of relevant reports, analyses and legislation on the subject provided an overview, which we have used to map the individual Nordic countries, the UK and the Netherlands, including the structure of their educational systems and the use of tuition fees and scholarships. To be sure that we were referring to the latest reports, analyses and legislation, we asked interviewees to identify relevant documents on the topic.

\section{Review of relevant websites}

A systematic review of relevant websites, particularly official ones such as studyindenmark.dk, and the sites of the individual HE institutions provided a detailed overview of practice in the individual countries, including policy and procedures at both institutional and national level. The review of the HE institutions' websites also provided contact details with relevant subjects for the qualitative interviews.

\subsubsection{Fieldwork}

\section{Interviews with representatives of relevant public-sector agencies in the Nordic Region}

The two main purposes of the interviews with representatives of the Nordic ministries were to obtain input for the mapping of the five Nordic countries and information about the effects of the introduction of tuition fees. The interviewees were asked:

- how each of the countries uses tuition fees.

- how each of the countries uses scholarships.

- what form fees take/how they are managed. 
- whether any students are exempted from fees.

- what relevant data and analyses have been published about the issue.

The Nordic Council of Ministers provided Oxford Research with contact details for fees experts. The following people were interviewed:

Table 13: Interviewees from public-sector agencies

\begin{tabular}{|c|c|c|}
\hline Person & Title & Body \\
\hline Jacob Fuchs & Head of Division & $\begin{array}{l}\text { Danish Agency for Universities and Interna- } \\
\text { tionalisation }\end{array}$ \\
\hline Kim Niemann & Analyst & $\begin{array}{l}\text { Danish Agency for Universities and Interna- } \\
\text { tionalisation }\end{array}$ \\
\hline Jonas Husum Johannesen & Head of Section & $\begin{array}{l}\text { Danish Agency for Universities and Interna- } \\
\text { tionalisation }\end{array}$ \\
\hline Åsa Petri & Deputy Director & $\begin{array}{l}\text { Swedish Ministry of Education and Re- } \\
\text { search }\end{array}$ \\
\hline Rolf L. Larsen & Deputy Director General & $\begin{array}{l}\text { Norwegian Ministry of Education and } \\
\text { Research }\end{array}$ \\
\hline Erling Dietrichson & Senior Advisor & $\begin{array}{l}\text { Norwegian Ministry of Education and } \\
\text { Research }\end{array}$ \\
\hline Birgitta Vuorinen & Counsellor for Education & Finnish Ministry of Education \\
\hline Carita Blomqvist & $\begin{array}{l}\text { Head of Unit Recognition and } \\
\text { International Comparability of } \\
\text { Qualifications }\end{array}$ & European networks - ENIC-NARIC \\
\hline Hardardottir Fridrika & Special Advisor & $\begin{array}{l}\text { The Icelandic Ministry of Education, Science } \\
\text { and Culture }\end{array}$ \\
\hline Dr Christian Yeomans & Policy Advisor & UK Higher Education International Unit (IU) \\
\hline
\end{tabular}

\section{Interviews with representatives of educational institutions/ organisations}

Interviews with representatives of educational institutions/organisations provided important input into the mapping of the individual countries, as well as specific knowledge of how the individual institutions have adapted their tuition-fee systems and scholarships. The qualitative interviews also informed the statistical data by providing an understanding of the actual situation faced by HE institutions.

To identify the most relevant interviewees, Oxford Research studied HE institutions' websites and interviewed the people listed in Table 14, below. 
Table 14: Interviewees from Nordic educational institutions/organisations

\begin{tabular}{|c|c|c|}
\hline Person & Title & Educational institution/organisation \\
\hline John Edelgaard Andersen & $\begin{array}{l}\text { Head of Department, the International } \\
\text { Office }\end{array}$ & University of Copenhagen \\
\hline Merete Reuss & $\begin{array}{l}\text { Head of the Office for Study Pro- } \\
\text { grammes and Student Affairs }\end{array}$ & Technical University of Denmark \\
\hline Ulla Bo Gjørling & $\begin{array}{l}\text { International Director, International } \\
\text { Centre }\end{array}$ & Aarhus University \\
\hline Anne Mette Hou & Head of Admissions and State Grants & Copenhagen Business School \\
\hline Lene Rehder & Head of Study Administration & IT University of Copenhagen \\
\hline Inger Rossing & $\begin{array}{l}\text { Director of Education and Internation- } \\
\text { alisation }\end{array}$ & Roskilde University \\
\hline Eva Marie Althoff Schäfer & Academic Officer, International Office & Aalborg University \\
\hline Jens Oddershede & Rector and Chairperson & $\begin{array}{l}\text { University of Southern Denmark and } \\
\text { Universities Denmark }\end{array}$ \\
\hline Søren Clemmensen & $\begin{array}{l}\text { Former Head of Education and } \\
\text { Consultant }\end{array}$ & Danish Vocational Schools \\
\hline Elisabeth Idermark & Senor Adviser for International Affairs & Stockholm University \\
\hline Eva Carling & $\begin{array}{l}\text { Coordinator, Strategic International } \\
\text { Affairs }\end{array}$ & University of Gävle \\
\hline Eva Wiberg & Pro Vice-Chancellor & Lund University \\
\hline Lars Holberg & Director of International Relations & Linköping University \\
\hline Fredrik Andersson & Assistant Secretary General & $\begin{array}{l}\text { The Association of Swedish Higher } \\
\text { Education (SUHF) }\end{array}$ \\
\hline Guri Vestad & $\begin{array}{l}\text { Section Manager, International } \\
\text { Education Office }\end{array}$ & University of Oslo \\
\hline Elli Zachariadis & $\begin{array}{l}\text { Principle Officer, Division of Student } \\
\text { Affairs }\end{array}$ & University of Bergen \\
\hline Hilde Skeie & $\begin{array}{l}\text { Head of Section, Office of Internation- } \\
\text { al Relations }\end{array}$ & $\begin{array}{l}\text { Norwegian University of Science and } \\
\text { Technology - NTNU Trondheim }\end{array}$ \\
\hline Jason Wertz & International Marketing Co-ordinator & BI Norwegian Business School \\
\hline Peter Maassen & Director & $\begin{array}{l}\text { Higher Education Development Association } \\
\text { (HEDDA) }\end{array}$ \\
\hline Ola Stave & General Secretary & $\begin{array}{l}\text { Norwegian Association of Higher Education } \\
\text { Institutions (UHR) }\end{array}$ \\
\hline Marjo Posti & International Co-ordinator & University of Helsinki \\
\hline Janne Hokkanen & Director for International Affairs & Lappeenranta University of Technology \\
\hline Kaija Holli & Chairperson & Finnish Council of University Rectors \\
\hline Leasa Weimer & Phd student & $\begin{array}{l}\text { University of Georgia, visiting Finnish } \\
\text { Institute for Educational Research }\end{array}$ \\
\hline Karitas Kvaran & Director, International Office & University of Iceland \\
\hline
\end{tabular}

\section{Interviews with NMP co-ordinators}

A number of the co-ordinators were interviewed in order to obtain input, learn about the most recent experiences of the impact of the introduction of tuition fees on Nordic mobility and assess the potential barriers and opportunities they create for NMP programmes. 


\begin{tabular}{lll} 
Table 15: Interviewees from NMP programmes & NMP programme \\
\hline Person & Title & $\begin{array}{l}\text { Viking and Medieval Norse } \\
\text { Studies }\end{array}$ \\
\hline Torfi Tulinius & Professor, University of Iceland & Aquatic Food Production \\
Caroline Baron & $\begin{array}{l}\text { Senior Researcher, Technical University of } \\
\text { Denmark }\end{array}$ & \\
Philip Binning & Professor, Technical University of Denmark & Environmental Engineering \\
Jaan-Henrik Kain & $\begin{array}{l}\text { Associate Professor, Chalmers University of } \\
\text { Technology }\end{array}$ & Sustainable Urban Transitions \\
Bente Eriksen Molau & Senior Lecturer, University of Gothenburg & Biodiversity and Systematics \\
Andrew Martin & Professor, KTH Royal Institute of Technology & $\begin{array}{l}\text { Innovation Sustainable Energy } \\
\text { Engineering }\end{array}$ \\
Anne Mette Holt & Chief Advisor, Technical University of Denmark & Former NMP co-ordinator \\
\hline
\end{tabular}





\section{Sammenfatning}

Dette studie vedrører de nordiske landes praksis i forhold til betalingsuddannelser for internationale studerende.101

Studiet er baseret på tre komplementerende dele. Den første del består af en kortlægning af den nuværende status for indførelsen af betalingsuddannelser for internationale studerende i de respektive nordiske lande. Det sker ved at se på hvem der betaler for videregående uddannelser, antallet af internationale studerende samt praksis vedrørende stipendier for internationale studerende. Den anden del af studiet afdækker konsekvenserne ved indførelsen af betalingsuddannelser i de nordiske lande. Her afdækkes internationale studerendes tilgang til det videregående uddannelsesområde i de nordiske lande - før og efter betalingsuddannelser er indført. Studiet giver i denne del flere forklaringer på udviklingen i antallet af internationale studerende. Den sidste og tredje del af studiet fremlægger de fremadrettede potentielle perspektiver for udviklingen af området i en nordisk kontekst.

Kortlægningen af betalingsuddannelser i de nordiske lande viser, at tre ud af de fem nordiske lande har indført betalingsuddannelser for internationale studerende på det videregående uddannelsesområde. Kortlægningen viser endvidere, at der er forskel på praksis på tværs af de nordiske lande, hvor betalingsuddannelser er indført. Danmark indførte betalingsuddannelser i 2006, og er det nordiske land med størst erfaring på området. Sverige indførte betalingsuddannelser på det videregående uddannelsesområde i 2011, hvorfor deres erfaringer på nuværende tidspunkt er begrænset. Finland er det tredje og sidste af de nordiske lande, der har indført betalingsuddannelser for internationale studerende. Finland har indført en prøveperiode for betalingsuddannelser fra 2010-2014 bestående af 24 uddannelsesprogrammer ved 9 forskellige videregående uddannelsesinstitutioner. Norge og Island har på nuværende tidspunkt ikke indført betalingsuddannelser for internationale studerende. I disse lande er det således muligt for alle studerende at gennemføre en videregående, statslig uddannelse gratis.

Konsekvenserne ved indførelsen af betalingsuddannelser på tværs af de nordiske lande er meget forskelligartet. For de nordiske lande, der har indført betalingsuddannelser på hele det videregående uddannelsesom-

101 Internationale studerende skal i denne kontekst forstås som non EU/EøS-studerende, undtaget Norge, Liechtenstein og Schweiz. 
råde, som det er tilfældet for Danmark og Sverige, er antallet af internationale studerende umiddelbart faldet markant. I Danmark er denne udvikling efterfulgt af en betydelig stigning i antallet af internationale studerende to til tre år efter indførelsen af betalingsuddannelser. Det, som en konsekvens af et stort antal stipendier øremærket internationale studerende, lige såvel som stigende marketingsinitiativer. I Sverige er antallet af internationale studerende også faldet markant efter indførelsen af betalingsuddannelser. Fra ca. 8.000 internationale studerende i 2010 til ca. 2.000 i 2011. I både Danmark og Sverige er faldet i antallet af internationale studerende primært drevet af færre studerende fra Asien.

I Finland er konsekvenserne af prøveperioden på nuværende tidspunkt for begrænsede til at opnå en klar forståelse af betydningen af denne. De to universiteter, der på nuværende tidspunkt har flest programmer tilknyttet prøveperioden for betalingsuddannelser, fortsætter dette ind til 2014. Det muliggør yderligere erfaringsindsamling på området, inden der tages en beslutning på området.

I Norge og Island er antallet af internationale studerende steget markant de seneste 5-7 år. Denne stigning er primært båret af internationale studerende fra lande uden for EU/EØS. Det indikerer, at disse typer af internationale studerende i højere grad tilvælger Norge og Island, når der indføres betalingsuddannelser i de andre nordiske lande.

De fremadrettede perspektiver for betalingsuddannelser på det videregående uddannelsesområde i Norden viser, at valget om indførelsen af betalingsuddannelser er formet af flere forhold. Det er et valg, der er formet af den politiske debat i de respektive nordiske lande, under hensyntagen til de fordele og ulemper betalingsuddannelser kan have for landene. Denne diskussion og afvejning er i et fremadrettet perspektiv afhængig af flere faktorer. Det være sig landenes syn på omfanget af velfærdsstaten, landenes økonomiske formåen samt hvilken rolle landene anser internationale studerende i den fremadrettede økonomiske udvikling. 
Ved Stranden 18

DK-1061 København K

www.norden.org

\section{Tuition fees for international students}

Nordic practice

This three-part study looks at tuition fees for international students in the Nordic Region. Part one maps the current status in the different countries. Part two looks at the impact of fees, e.g. by comparing international student numbers before and after the introduction of fees. The final part looks at potential future scenarios for tuition fees in a Nordic context.

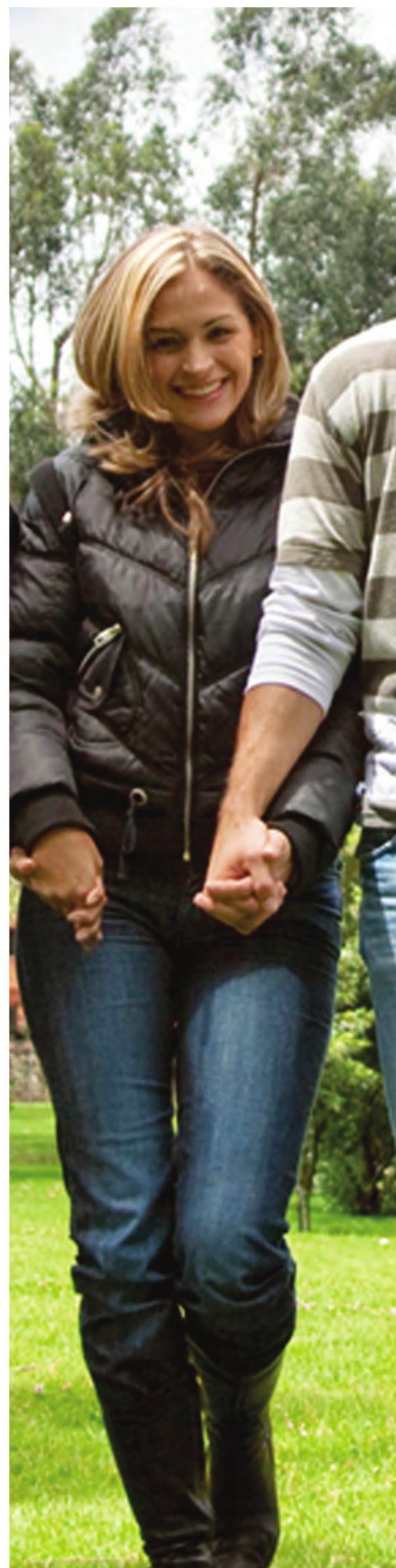

